\title{
Five new species of Acanthobothrium (Cestoda: Tetraphyllidea) from an unusual species of Himantura (Rajiformes: Dasyatidae) from northern Australia
}

\author{
Carrie A. Fyler ${ }^{1}$, Janine N. Caira ${ }^{1}$ and Kirsten Jensen ${ }^{2}$ \\ ${ }^{1}$ Department of Ecology \& Evolutionary Biology, University of Connecticut, Unit 3043, 75 N. Eagleville Rd., Storrs, Connecticut \\ 06269-3043, USA; \\ ${ }^{2}$ Department of Ecology \& Evolutionary Biology \& Biodiversity Research Center, University of Kansas, 1200 Sunnyside Ave., \\ Lawrence, Kansas 66045, USA
}

\begin{abstract}
Five new species of Acanthobothrium van Beneden, 1850 from the spiral intestine of a specimen of an unusual species of Himantura from the Arafura Sea off northern Australia are described. Acanthobothrium oceanharvestae sp. $\mathrm{n}$. is one of 26 category 1 species (sensu Ghoshroy and Caira 2001) lacking post-ovarian testes; it differs from these in total length, number of proglottids, number of testes, cirrus sac size and details of the terminal genitalia. Acanthobothrium popi sp. n. is unique among category 2 species in its possession of post-ovarian testes. Acanthobothrium rodmani sp. $\mathrm{n}$. is a category 6 species distinct from all congeners in the dense blade-like spinitriches on the distal surfaces of its anterior-most bothridial loculi and conspicuously tapered posterior bothridial margins, which are reflexed anteriorly. Acanthobothrium romanowi sp. n. differs from most other category 1 species in that its genital pore is distinctly posterior. It differs from the remaining category 1 species in size, testis number, cephalic peduncle microthrix form, proglottid shape, and bothridial loculus dimensions. Acanthobothrium zimmeri sp. $\mathrm{n}$. is among the six category 1 species with post-ovarian testes. It differs from these species in total length, ovary shape, number of proglottids and testes and vas deferens extent. This brings the number of Acanthobothrium species with post-ovarian testes to 10, all of which are Indo-Pacific in distribution, and 7 of which parasitize Himantura species. A key to the five new species parasitizing Himantura sp. is provided. Sequence data for the D1-D3 region of 28S rDNA for the five new species and two congeners parasitizing other Himantura species shows no intraspecific variation. Analysis of these and comparable data for two species available in GenBank (Acanthobothrium parviuncinatum and Acanthobothrium sp. 1) showed an interspecific variation of $0.7-11.3 \%$ among species pairs. Bayesian, Likelihood and Parsimony phylogenetic analyses of these data for these nine species indicate that the five new species parasitizing Himantura sp. are generally not each others' closest relatives.
\end{abstract}

Key words: Cestoda, Tetraphyllidea, Acanthobothrium, Himantura, 28S rDNA, Australia

The tetraphyllidean genus Acanthobothrium van Beneden, 1850 is both a ubiquitous and conspicuous component of the cestode fauna of species of the Indo-Pacific stingray genus Himantura Müller et Henle examined to date (e.g., Srivastav and Capoor 1980, Campbell and Beveridge 2002, Fyler and Caira 2006, Reyda and Caira 2006, Twohig et al. 2008). In such systems, Acanthobothrium species appear to exhibit oioxenous specificity for their stingray hosts. In addition, it is not uncommon to find multiple members of the genus parasitizing a single species of Himantura (see Campbell and Beveridge 2002, Fyler and Caira 2006, Reyda and Caira 2006). The opportunity for JNC and $\mathrm{KJ}$ to spend time on a commercial trawling vessel working in the Arafura Sea off northern Australia, provided access to some of the larger species of batoids not yet examined for cestodes and that would have been difficult to obtain otherwise. Among the animals examined, was a specimen of what appears to be an undescribed large species of Himantura, which will be referred to throughout as Himantura sp. This animal was found to host a diverse cestode fauna that included five new species of Acanthobothrium; these are described below. Sequence data for partial (D1-D3) 28S rDNA were generated for these five species and two of their congeners from other Himantura species and, in combination with comparable GenBank data for two additional species of Acanthobothrium, were used to test whether congeners parasitizing the same host species are each others' closest relatives. 


\section{MATERIALS AND METHODS}

The specimen of Himantura sp. examined was a mature female (disk width: $161 \mathrm{~cm}$; disk length: $174 \mathrm{~cm}$ ) with one pup, caught in the Arafura Sea, east of the Wessel Islands, Northern Territory, Australia $\left(11^{\circ} 17^{\prime} 44^{\prime \prime} \mathrm{S}, 136^{\circ} 59^{\prime} 48^{\prime \prime} \mathrm{E}\right)$ using a bottom trawl set to $\sim 60 \mathrm{~m}$, on November 17, 1999. The ray and her pup were photographed, and 3 samples of liver tissue from the female were taken and placed in 95\% ethanol. The spiral intestine was removed and opened with a longitudinal incision. A preliminary examination of the spiral intestine for cestodes was conducted and worms found were divided into two lots; one lot of worms was fixed in $10 \%$ formalin buffered in seawater (1:9), the second lot was fixed in $95 \%$ ethanol for molecular work. The spiral intestine was fixed in $10 \%$ formalin buffered in seawater (1:9) and subsequently transferred to $70 \%$ ethanol for storage, as were the formalin-fixed worms.

\section{Morphological data}

Formalin-fixed material was prepared for examination with light and scanning electron microscopy (SEM), and also as histological sections. A subsample of the cestodes fixed in formalin were prepared as whole mounts as follows. They were hydrated in a graded series of ethanols, stained in Delafield's haematoxylin, dehydrated in a graded series of ethanols, cleared in methyl salicylate and mounted on glass slides in Canada balsam. One to six specimens of each cestode species found were prepared for examination with the scanning electron microscope. In these cases, the scolex was removed and the strobila was prepared as a whole mount as described above to serve as a voucher for specimens scanned. The scolex was hydrated in a graded ethanol series, placed in $1 \% \mathrm{OsO}_{4}$ overnight, dehydrated in a graded ethanol series, transferred to hexamethyldisilizane (HMDS) (Ted Pella, Inc., Redding, California), and allowed to air dry. They were subsequently mounted on double-sided carbon tape or PELCO carbon conductive tabs (Ted Pella, Inc., Redding, California) on aluminium stubs, coated with $35-\mathrm{nm}$ gold/palladium, and examined with a LEO/Zeiss DSM982 Gemini field emission scanning electron microscope.

The proglottids of 1 to 2 formalin-fixed specimens of each species were prepared for histological examination as follows. Each specimen was divided approximately in half and the anterior portion was prepared as a whole mount as described above to serve as a voucher for the specimen sectioned. The posterior portion was embedded in Paraplast, and 7-8 $\mu \mathrm{m}$ serial crosssections were cut using an Olympus CUT4060 retracting rotary microtome. Sections were mounted on slides flooded with $10 \%$ aqueous sodium silicate and allowed to dry. These were subsequently stained in Gill's or Delafield's haematoxylin, differentiated in Scott's solution, counterstained in eosin, cleared in xylene, and mounted on glass slides in Canada balsam. Finally, in order to explore its unusual scolex morphology, cross- and longitudinal sections of the scolex of the largest of the new species were also prepared. In these cases, the strobila was prepared as a whole mount to serve as a voucher.

Images were taken with a Leica DFC 480 digital camera or SPOT Diagnostic Instrument digital camera, mounted on a Zeiss Axioskop 2 compound microscope. Measurements were made using either an ocular reticle or with a SPOT digital camera and SPOT software (version 4.5). Hook measurements taken follow Euzet (1959) as modified by Ghoshroy and Caira (2001). Measurements are given in the text as ranges; mean, standard deviation, number of specimens examined and number of measurements taken are provided in Table 1. All measurements are in micrometres unless otherwise stated. Museum abbreviations are as follows: IPCAS, Institute of Parasitology, Biology Centre ASCR, České Budějovice, Czech Republic; LRP, Lawrence R. Penner Parasitology Collection, Department of Ecology \& Evolutionary Biology, University of Connecticut, Storrs, Connecticut, USA; QM, Queensland Museum, Brisbane, Queensland, Australia; USNPC, U.S. National Parasite Collection, Beltsville, Maryland, USA. Terminology for molecular voucher specimens follows Pleijel et al. (2008). Thus, all molecular vouchers are hologenophores as they represent the same individual organism as was used for the molecular work conducted. Use of the terms spinithrix and filithrix follows Faliex et al. (2000).

\section{Molecular data}

Taxon sampling. For the purposes of phylogenetic analyses, molecular data were generated for 2 specimens of each of the 5 new species of Acanthobothrium and also, for comparative purposes, for 2 specimens of Acanthobothrium masnihae Fyler et Caira, 2006 from the freshwater whipray, Himantura polylepis (Bleeker) (as Himantura chaophraya Monkolprasit et Roberts) from Borneo and for 2 specimens of an undescribed species of Acanthobothrium from the Tubemouth whipray, Himantura lobistoma Manjaji-Matsumoto et Last from Borneo. Also included in these analyses were 2 previously sequenced species of Acanthobothrium for which hologenophores and 28S rDNA data were available from GenBank: Acanthobothrium parviuncinatum Young, 1954 from Urobatis maculatus Garman of Waeschenbach et al. (2007) (EF095264) and Acanthobothrium sp. 1 from Dasyatis longus (Garman) of Olson et al. (2001) (AF286953), both from the Gulf of California in Mexico.

With respect to the selection of outgroups, the position of the genus Acanthobothrium within the larger framework of tetraphyllidean cestodes is unclear. The molecular work of Olson et al. (2001), Caira et al. (2005), and Healy et al. (2009) suggests that the genus is most closely related to the Proteocephalidea, a relatively speciose order of tapeworms parasitic primarily in freshwater teleosts, but also in some amphibians and reptiles. Thus, the outgroup consisted of 3 species representing some of the more basal lineages of proteocephalideans, as determined by Zehnder and Mariaux (1999) and de Chambrier et al. (2004), for which comparable data were available from GenBank. These were Acanthotaenia sp. (AJ388593), Gangesia parasiluri Yamaguti, 1934 (AJ388590) and Silurotaenia siluri (Batsch, 1786) Nybelin, 1942 (AJ388592).

Molecular Techniques. A portion of the nuclear large subunit 28S rDNA (D1-D3; 1,300 nucleotides) gene was selected based on its previous established utility in resolving interspecific phylogenetic relationships in other cestode groups (e.g., Zehnder and Mariaux 1999, Olson et al. 2001, de Chambrier et al. 2004, Caira et al. 2005, Waeschenbach et al. 2007). DNA was extracted from the midsection of worms preserved in $95 \%$ ethanol and the terminal proglottid(s) and scolex of each was prepared as a whole mount to serve as a voucher for the specimens from which sequence data were generated. These hologenophores have been deposited in the LRP. Accession numbers for the new species collected from Himantura sp. are provided in the taxonomic summaries below. Vouchers for the remaining species are as follows: A. masnihae (LRP 4555-4556) and Acanthobothrium sp. 1 (LRP 4557-4558). 
Total genomic DNA was extracted using the standard phenol-chloroform protocol (Hillis et al. 1996). PCR primers used in this study were obtained from previously published studies and included the forward primer LSU5 (5'-TAGGTCGACCCGCTGAAYTTAAGCA-3') and the reverse primers 1200R (5'-GCATAGTTCACCATCTTTCGG-3') and 1500R (5'-GCTATCCTGAGGGAAACTTCG-3'). PCR was performed in $25 \mu 1$ reactions using 2-100 ng of template DNA, $0.25 \mu \mathrm{M}$ each of the primers LSU5 and $1500 \mathrm{R}, 1 \mu \mathrm{M} \mathrm{MgCl}_{2}$, $0.12 \mu \mathrm{M}$ each of dNTP, 1.25 units of Taq DNA polymerase and using an annealing temperature of $56^{\circ} \mathrm{C}$. Cycling conditions were as follows: initial denaturation for $1 \mathrm{~min}$ at $94^{\circ} \mathrm{C}$, followed by 40 cycles of $30 \mathrm{~s}$ at $94^{\circ} \mathrm{C}, 30 \mathrm{~s}$ at $56^{\circ} \mathrm{C}, 1 \mathrm{~min}$ at $72^{\circ} \mathrm{C}$ and completed by $5 \mathrm{~min}$ at $72^{\circ} \mathrm{C}$. PCR products were purified using Nucleospin ${ }^{\circledR}$ Extraction Kit (BD Biosciences), cycle sequenced with primer pair LSU5 and 1200R using Big Dye ${ }^{\mathrm{TM}}$ dideoxy terminators version 1.1 and sequenced on an Applied Biosystems ABI PRISM ${ }^{\circledR} 3100$ Genetic Analyzer. Contiguous sequences were assembled using SEQUENCHER 4.1.2 ${ }^{\mathrm{TM}}$ (GeneCodes Corporation). Sequences were aligned initially with MAFFT v6.240 (Kyoto University Bioinformatics Center) using the LINS-I strategy and default parameters and then adjusted by eye in MacClade 4 (Maddison and Maddison 2005).

Phylogenetic Analyses. Bayesian inference (BI), Maximum likelihood (ML) and Maximum parsimony (MP) analyses were performed on the $28 \mathrm{~S}$ rDNA data. In all cases, gaps were treated as missing data (i.e., “?”). BI and ML analyses were performed under the model of sequence evolution determined to be most appropriate using the hierarchical likelihood ratio test as implemented by MrModeltest version 1.1b (a variant of Modeltest; Posada and Crandall 1998, Nylander 2004). BI phylogenetic analyses were conducted using the software MrBayes 3.0b4 (Ronquist and Huelsenbeck 2003) with 4 independent Markov chains ( 1 cold and 3 incrementally heated chains) run for 5 million metropolis-coupled MCMC generations (trees sampled at intervals of 1,000 generations). Stationarity was determined by plotting log-Likelihood ( $\operatorname{lnL}$ ) scores against number of generations, and was assumed at the point at which likelihood scores levelled off after an initial burn-in. A number of trees were excluded as burn-in; posterior probabilities and tree topologies were based on a $50 \%$ majority rule consensus of the remaining post burn-in trees. Three separate BI analyses were run to ensure convergence on the same posterior distribution as evident from similar topologies and mean $\mathrm{lnL}$ scores. The posterior distribution of each parameter was analysed using the MCMC Trace Analysis Tool, Tracer (Rambaut and Drummond 2005; ver. 1.2.1). The frequency with which a particular clade was present in the estimated posterior distribution is represented by the clade's posterior probability (PP). Posterior probabilities were mapped onto the Bayesian consensus phylogram; nodes with PP $>0.95$ were considered to be strongly supported (Wilcox et al. 2002). ML heuristic searches were run using GARLI (Zwickl 2006). Three separate GARLI analyses were run to ensure convergence on the same best tree, as evident from similar topology and $\operatorname{lnL}$ scores. Nodal support for the inferred ML clades was estimated by bootstrap analysis (100 bootstrap replicates). Clades with bootstrap values of $\geq 70 \%$ were considered strongly supported (Hillis and Bull 1993). MP analyses were run using the branch-and-bound algorithm in PAUP ${ }^{\star} 4.0 \mathrm{~b} 10$ (Swofford 2002). All characters were treated as unordered and equally weighted. Nodal support for MP analyses was assessed using bootstrap re-sampling (1,000 bootstrap replicates; branch-andbound algorithm). Pairwise base differences were calculated using PAUP ${ }^{\star} 4.0 \mathrm{~b} 10$ (Swofford 2002). These were reported as the proportion of sites differing between each Acanthobothrium species pair as percentages and number of substitutions out of total number of bases (excluding gaps and ambiguous sites).

Host. With respect to the specimen of Himantura sp. (host specimen No. NT-96), DNA was extracted from a sample of liver tissue preserved in $95 \%$ ethanol and NADH dehydrogenase subunit 2 (ND2) sequence data were generated. These data were compared, using Neighbor-joining analysis conducted in PAUP $^{\star} 4.0 \mathrm{~b} 10$ (Swofford 2002), with similar data for 15 other Indo-Pacific species of Himantura generated as part of a larger study of elasmobranch identity globally. This work was conducted by Dr. Gavin Naylor of Florida State University, Tallahassee, Florida, USA.

\section{RESULTS}

\section{Acanthobothrium oceanharvestae sp. n.}

Figs. 1-5, 10-13, 49

Description (based on whole mounts of 7 mature worms, cross-sections of mature proglottids of 1 worm and whole mount of its voucher, 4 scoleces examined with SEM and whole mounts of their vouchers, and the scoleces and posterior portion of the strobila of 2 hologenophores): Worms 2.9-3.7 mm long; greatest width at level of scolex; 10-14 proglottids per worm; euapolytic; genital pores marginal, irregularly alternating, 60-66\% of proglottid length from posterior end. Scolex consisting of scolex proper and conspicuous cephalic peduncle. Scolex proper with 4 bothridia, 380-470 long by 255-314 wide. Bothridia free posteriorly, 126-170 wide; each with 3 loculi and specialised anterior region in form of muscular pad; muscular pad 77-120 long by 106-136 wide, bearing apical sucker and 1 pair of hooks below posterior margin, triangular in shape, posterior margins pronounced; apical sucker 35-53 long by 43-59 wide; anterior loculus 160-190 long; middle loculus 68-85 long; posterior loculus 75-110 long; loculus length ratio (anterior:middle:posterior) 1:0.39-0.50:0.42-0.64; maximum width of scolex at level of middle loculus. Velum present between medial margins of adjacent bothridia at posterior margin of middle loculus. Hooks bipronged, hollow, with tubercle on proximal surface of axial prong; internal channels of axial and abaxial prongs continuous, smooth; axial prongs slightly longer than abaxial prongs; lateral and medial hooks approximately equal in size. Lateral hook measurements: A 43-51, B 86-98, C 71-81, D 124-136. Medial hook measurements: A' 38-48, B' 90106, C' 66-83, D' 127-144. Bases of lateral and medial hooks approximately equal in length; base of lateral hook overlapping and slightly wider than medial hook base. Bases of hooks embedded in musculature of bothridial pad. Cephalic peduncle 188-385 long by $59-90$ wide at 
mid-level. Apical pad (Fig. 11) and distal bothridial surfaces covered with short filitriches. Proximal bothridial surfaces with blade-like spinitriches (Fig. 12) interspersed with long filitriches throughout. Long filitriches conspicuous at bothridial rims. Cephalic peduncle covered with densely arranged blade-like spinitriches (Fig. 13) interspersed with relatively long filitriches.

Proglottids acraspedote, protandrous. Immature proglottids 9-13 in number; mature proglottid 1 in number. Terminal mature proglottid $822-1,237$ long by $164-215$ wide, length:width ratio 4.1-7.2:1. Gravid proglottids not observed. Testes irregularly oval in dorsal or ventral view, $30-55$ long by $32-66$ wide, arranged in 2 regular columns anterior to ovarian isthmus, 1 layer deep, 28-40 in total number, 6-11 in postporal field, none posterior to ovarian isthmus, conspicuous in mature proglottids. Cirrus sac ovoid, bent slightly anteriorly, 91-128 long by 45-96 wide, containing coiled cirrus; base and some of length of cirrus covered with spinitriches. Vagina thick-walled, weakly sinuous, 500-744 long, extending from ootype along medial line of proglottid to anterior margin of cirrus sac then laterally following anterior margin of cirrus sac to common genital atrium; vaginal sphincter absent; seminal receptacle not seen. Ovary occupying posterior half of proglottid, essentially symmetrical, 380-711 long, 68-108 wide at level of isthmus, H-shaped in frontal view, bilobed in cross-section, weakly lobulated; ovarian isthmus in posterior third of ovary; Mehlis' gland posterior to ovarian isthmus. Vitellarium follicular, consisting of 2 lateral bands; each band consisting of 2 columns of relatively small follicles, extending from near anterior margin of proglottid to near posterior of ovary, interrupted by vagina and cirrus sac, not interrupted by ovary; vitelline follicles irregular, 9-24 long by 12-25 wide. Uterus thickwalled, sacciform, extending from near anterior margin of proglottid to posterior margin of ovarian isthmus. Excretory ducts lateral, in one dorsal and one ventral pair. Eggs not observed.

Type host: Himantura sp. (Rajiformes: Dasyatidae).

Type locality: Arafura Sea $\left(11^{\circ} 17^{\prime} 44^{\prime \prime} \mathrm{S}, 136^{\circ} 59^{\prime} 48^{\prime \prime} \mathrm{E}\right)$, east of Wessel Islands, Northern Territory, Australia.

Date of collection: November 17, 1999.

Site of infection: Spiral intestine.

Type material: Holotype (QM 231345), 2 paratypes (QM G231346-G231347), 2 paratypes (USNPC 101957101958), 2 paratypes (LRP 4317-4318), cross-sections of 1 paratype (QM 231349) and corresponding voucher (QM G231348), 4 paratypes prepared for SEM (LRP 4319-4320, 4327-4328), 2 paratype hologenophores (LRP 4321: GenBank No. FJ843594 [CF-93]; LRP 4322: GenBank No. FJ843595 [CF126]).

Additional material: Two vouchers (IPCAS C-522).

Etymology: This species is named for the commercial trawling vessel F. V. Ocean Harvest, in recognition of her having served so effectively as a lab, a home, and the source of the elasmobranch host from which this species was collected.
Remarks. Acanthobothrium oceanharvestae sp. n. is a category 1 species according to the categories of Acanthobothrium species determined by Ghoshroy and Caira (2001) (i.e., $\leq 15 \mathrm{~mm}$ in total length, $\leq 50$ proglottids, $\leq 80$ testes, with symmetrical ovary). At this point, 30 category 1 species are recognized (i.e., the 4 species described by Reyda and Caira [2006] and the 25 listed in their table 2, and A. marymichaelorum Twohig, Caira et Fyler, 2008). Acanthobothrium oceanharvestae conspicuously differs from $A$. foulki Reyda et Caira, 2006, A. larsoni Reyda et Caira, 2006, A. marymichaelorum, A. saliki Fyler et Caira, 2006 and $A$. southwelli Subhapradha, 1955 in its lack of post-ovarian testes. It differs from $A$. asnihae Fyler et Caira, 2006 and A. gnomus Reyda et Caira, 2006 in its lack of a weak horizontal band of musculature running across the posterior loculi. It is a shorter worm than A. paulum Linton, 1890, A. laurenbrownae Campbell et Beveridge, 2002, and A. mathiasi Euzet, 1959 (2.9-3.7 vs. 4.5-19, $5-16.7$, and $10-20 \mathrm{~mm}$, respectively). It is longer in total length than A. lepidum Reyda et Caira, 2006 and A. bartonae Campbell et Beveridge, 2002 (2.9-3.7 vs. 1.1-2.05 and $2.1 \mathrm{~mm}$, respectively). However, it further differs from A. lepidum in that its posterior loculus is not abruptly and conspicuously reduced in width relative to the anterior two loculi. It further differs from $A$. bartonae in that it lacks the lateral tubercles seen on the axial and abaxial prongs of the latter species and also possesses a genital pore that is conspicuously more anterior than that seen in A. bartonae. Acanthobothrium oceanharvestae sp. $\mathrm{n}$. has a greater number of testes than $A$. martini Campbell et Beveridge, 2002 and A. minusculus Marques, Brooks, et Barriga, 1997 (28-40 vs. 8-11 and 6-10, respectively) and fewer testes than A. dollyae Caira et Burge, 2001, A. fogeli Goldstein, 1964, A. guptai Shinde et Ghagwan, 2002, A. clarkeae Campbell et Beveridge, 2002, A. pearsoni Williams, 1962 and A. urolophi Schmidt, 1973 (28-40 vs. 42-55, 44-45, 44-45, 45-52, 56-60, 40-72, respectively). It further differs from $A$. urolophi in that its ovary occupies the posterior half, rather than the posterior one-quarter of the proglottid and in its possession of hooks with straight, relatively robust prongs, rather than with angled, delicate prongs. It possesses fewer proglottids than A. zainali Fyler et Caira, 2006, A. himanturi Brooks, 1977, A. marplatensis Ivanov et Campbell, 1998, A. royi Caira et Burge, 2001, and A. monksi Marques, Brooks et Barriga, 1997 (10-14 vs. 15-21, 17-26, 18-30, 19-26 and 21-48, respectively) and a greater number of proglottids than $A$. rohdei Campbell et Beveridge, 2002 (10-14 vs. 4-6). The new species possesses a conspicuously smaller cirrus sac than A. lineatum (length 91-124 vs. 135-265). Acanthobothrium oceanharvestae sp. n. differs from $A$. odonoghuei Campbell et Beveridge, 2002 in that it lacks the distinctive elongate hair-like microtriches seen on the cephalic peduncle of the latter species. It has wider bothridia than $A$. lintoni Goldstein, Henson et 

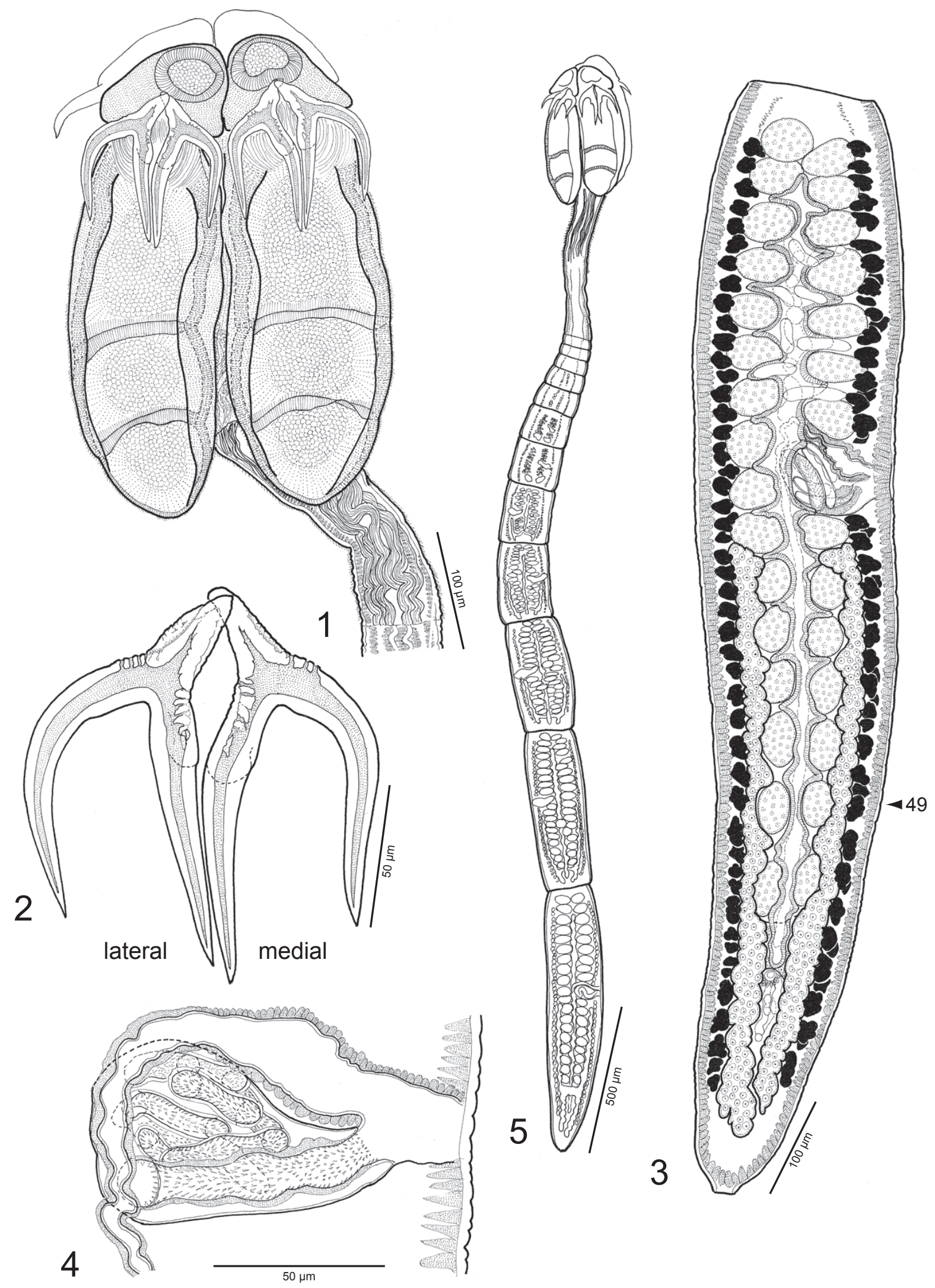

Figs. 1-5. Line drawings of Acanthobothrium oceanharvestae sp. n. Fig. 1. Scolex (QM G231345). Fig. 2. Hooks (QM G231345). Fig. 3. Terminal proglottid (QM G231345). Arrowhead indicates location of cross-section shown in Fig. 49. Fig. 4. Detail of terminal genitalia (USNPC 101958). Fig. 5. Whole worm (USNPC 101957). 

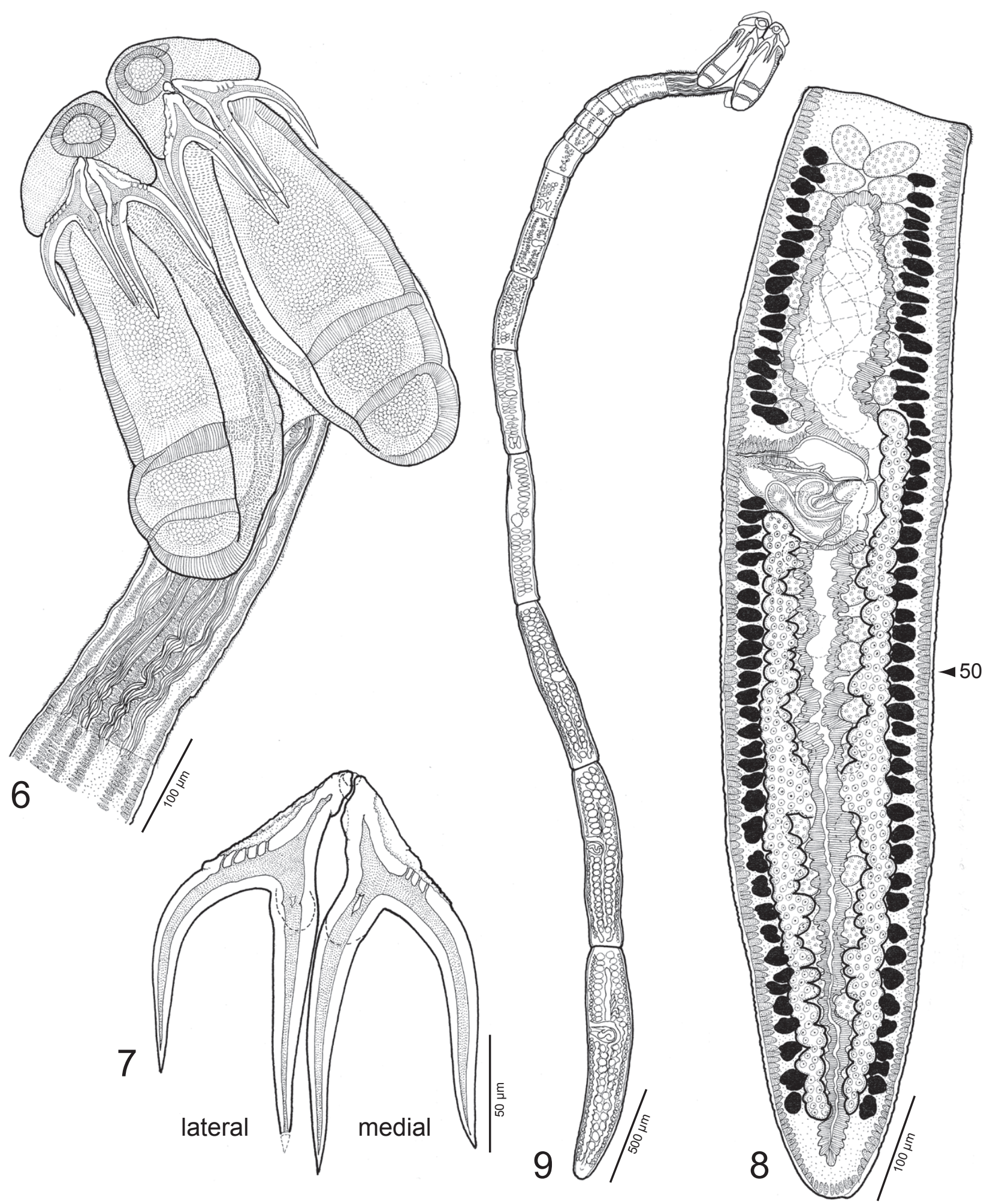

Figs. 6-9. Line drawings of Acanthobothrium popi sp. n. Fig. 6. Scolex (QM G231350). Fig. 7. Hooks (QM G231350). Fig. 8. Terminal proglottid (USNPC 101959). Arrowhead indicates location of cross-section shown in Fig. 50. Fig. 9. Whole worm (QM G231350). 

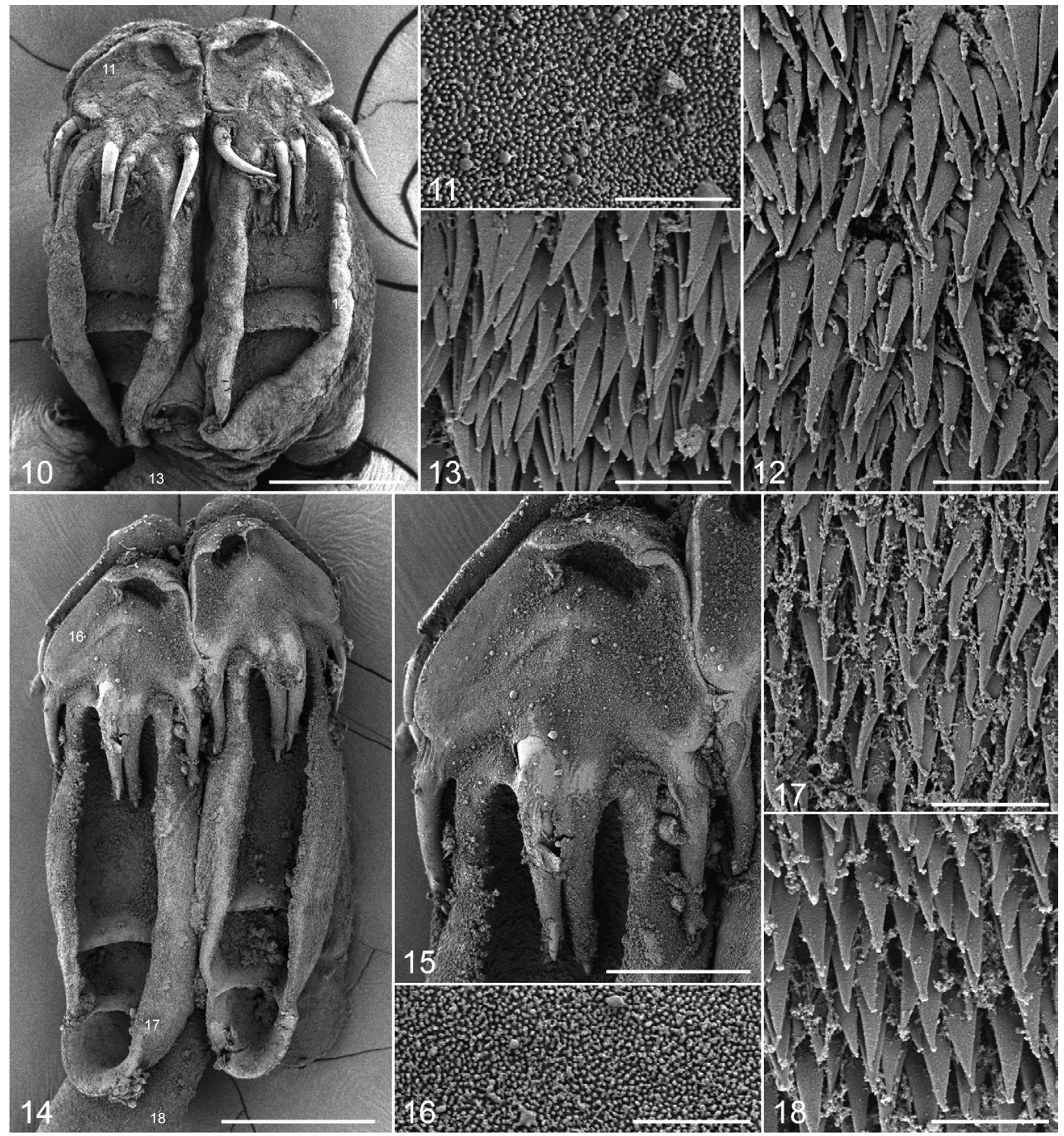

Figs. 10-13. Scanning electron micrographs of Acanthobothrium oceanharvestae sp. n. Fig. 10. Scolex. Note: small numbers correspond to the figures showing higher magnification images of these surfaces. Fig. 11. Surface of apical pad. Fig. 12. Proximal bothridial surface. Fig. 13. Cephalic peduncle surface. Figs. 14-18. Scanning electron micrographs of Acanthobothrium popi sp. n. Fig. 14. Scolex. Note: small numbers correspond to the figures showing higher magnification images of these surfaces. Fig. 15. Detail of apical pad and hooks. Fig. 16. Surface of apical pad. Fig. 17. Proximal bothridial surface. Fig. 18. Cephalic peduncle surface. Scale bars: Figs. 10, $14=100 \mu \mathrm{m}$; Fig. $15=50 \mu \mathrm{m}$; Figs. $11-13,16-18=2 \mu \mathrm{m}$.

Schlicht, 1969 (255-314 vs. 128-230) and also a longer cirrus sac (91-128 vs. 35-84). Acanthobothrium oceanharvestae sp. n. closely resembles $A$. nicoyaense Brooks et McCorquodale, 1995, but differs in that it lacks a prom- inent vaginal sphincter and also in that there was no evidence of the lateral protrusion that houses the genital pore (Fig. 4) such as that seen in the latter species. 
Acanthobothrium popi sp. n. Figs. 6-9, 14-18, 50

Description (based on whole mounts of 6 mature worms, 1 immature worm, cross-sections of mature proglottids of 1 worm, 4 scoleces examined with SEM and whole mounts of their vouchers, and the scoleces and posterior portion of the strobila of 2 hologenophores): Worms 3.95-7.1 mm long; greatest width at level of scolex; 14-20 proglottids per worm; euapolytic; genital pores marginal, irregularly alternating, $62-71 \%$ of proglottid length from posterior end. Scolex consisting of scolex proper and conspicuous cephalic peduncle. Scolex proper with 4 bothridia, $426-580$ long by $253-353$ wide. Bothridia free posteriorly, 130-190 wide; each with 3 loculi and specialised anterior region in form of muscular pad; muscular pad 88-118 long by 112-163 wide, bearing apical sucker and 1 pair of hooks below posterior margin, triangular in shape, with conspicuous apical thickening, posterior margins pronounced; apical sucker 44-66 long by $50-88$ wide; anterior loculus 193-282 long; middle loculus 53-93 long; posterior loculus 67-130 long; loculus length ratio (anterior:middle:posterior) 1:0.22-0.36: $0.32-0.48$; maximum width of scolex at level of middle loculus. Velum present between medial margins of adjacent bothridia at mid-level of middle loculus. Hooks bipronged, hollow, with tubercle on proximal surface of axial prong; internal channels of axial and abaxial prongs continuous, smooth; abaxial prongs slightly longer than axial prongs; lateral and medial hooks approximately equal in size. Lateral hook measurements: A 47-65, B 71-120, C 75-100, D 111-173. Medial hook measurements: A' 48-60, B' 75-119, C' 87-108, D' 120-175. Bases of lateral and medial hooks approximately equal in length; base of lateral hook overlapping and slightly narrower than medial hook base. Bases of hooks embedded in musculature of bothridial pad. Cephalic peduncle 328-450 long by 77-159 wide at mid-level. Apical pad (Figs. 15, 16) and distal bothridial surfaces covered with short filitriches. Proximal bothridial surfaces with bladelike spinitriches (Fig. 17) interspersed with long filitriches throughout. Bothridial margins with long filitriches. Cephalic peduncle covered with densely arranged blade-like spinitriches (Fig. 18) interspersed with relatively long filitriches.

Proglottids acraspedote, protandrous. Immature proglottids 13-18 in number; mature proglottid 1-2 in number. Terminal mature proglottid 954-1,320 long by 169-245 wide, length:width ratio 4.2-7.4:1. Gravid proglottids not observed. Testes irregularly oval in dorsal or ventral view, 28-50 long by 28-71 wide, arranged in 2 regular columns anterior and posterior to ovarian isthmus, 1 layer deep, 37-50 in total number, 5-9 in postporal field, 7-11 posterior to ovarian isthmus, conspicuous in mature proglottids. Cirrus sac ovoid, tilted slightly posteriorly, 108-152 long by 70-138 wide, containing coiled cirrus; cirrus expanded slightly at base; base and some of length of cirrus covered with spinitriches. Vagina thickwalled, sinuous, 430-607 long, extending from ootype along medial line of proglottid to anterior margin of cirrus sac then laterally following anterior margin of cirrus sac to common genital atrium; vaginal sphincter present; seminal receptacle not seen. Ovary occupying posterior two-thirds of proglottid, 93-145 wide at level of isthmus, $\mathrm{H}$-shaped in frontal view, bilobed in cross-section, weakly lobed, conspicuously asymmetrical; aporal arm 614-845 long, reaching well anterior to cirrus sac; poral arm 457-745 long, reaching posterior margin of cirrus sac; ovarian isthmus posterior to midpoint of ovary. Mehlis' gland posterior to ovarian isthmus. Vitellarium follicular, consisting of 2 lateral bands; each band consisting of 2 columns of relatively small follicles, extending from near anterior margin of proglottid to near posterior margin of proglottid, interrupted by vagina and cirrus sac, not interrupted by ovary; vitelline follicles irregularly shaped, 8-28 long by $13-25$ wide. Uterus thick-walled, sacciform, extending from near anterior margin of proglottid to near posterior margin of proglottid. Excretory ducts lateral, in one dorsal and one ventral pair. Eggs not observed.

Type host: Himantura sp. (Rajiformes: Dasyatidae).

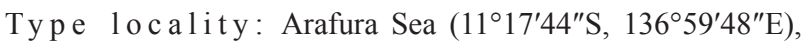
east of Wessel Islands, Northern Territory, Australia.

Date of collection: November 17, 1999.

Site of infection: Spiral intestine.

Type material: Holotype (QM G231350), 2 paratypes (QM G231351-G231352), 2 paratypes (USNPC 101959101960), 2 paratypes (LRP 4323-4324), cross-sections of 1 paratype and corresponding voucher (QM G231353), 4 paratypes prepared for SEM (LRP 4329-4330, 43254326), 2 paratype hologenophores (LRP 4331: GenBank No. FJ843600 [CF-111]; LRP 4332: GenBank No. FJ843601 [CF-120]).

Additional material: One voucher (IPCAS C-523).

Etymology: This species is named for the senior author's grandfather Anson C. Fyler ("Pop") in appreciation of his continued encouragement and support of her academic endeavours.

Remarks. Acanthobothrium popi sp. n. is a category 2 species according to the categories of Acanthobothrium species established by Ghoshroy and Caira (2001) (i.e., $\leq 15 \mathrm{~mm}$ in total length, $\leq 50$ proglottids, $\leq 80$ testes, with asymmetrical ovary). It is the only category 2 species that possesses post-ovarian testes.

\section{Acanthobothrium rodmani sp. $\mathrm{n}$.}

Figs. 19-22, 27-32, 51-54

Description (based on whole mounts of 10 mature worms, cross-sections of mature proglottids of 1 worm and whole mount of its voucher, 4 scoleces examined with SEM and whole mounts of their vouchers, cross-sections of scolex of 1 worm and whole mount of its voucher, longitudinal sections of scolex of 1 worm and whole mount 


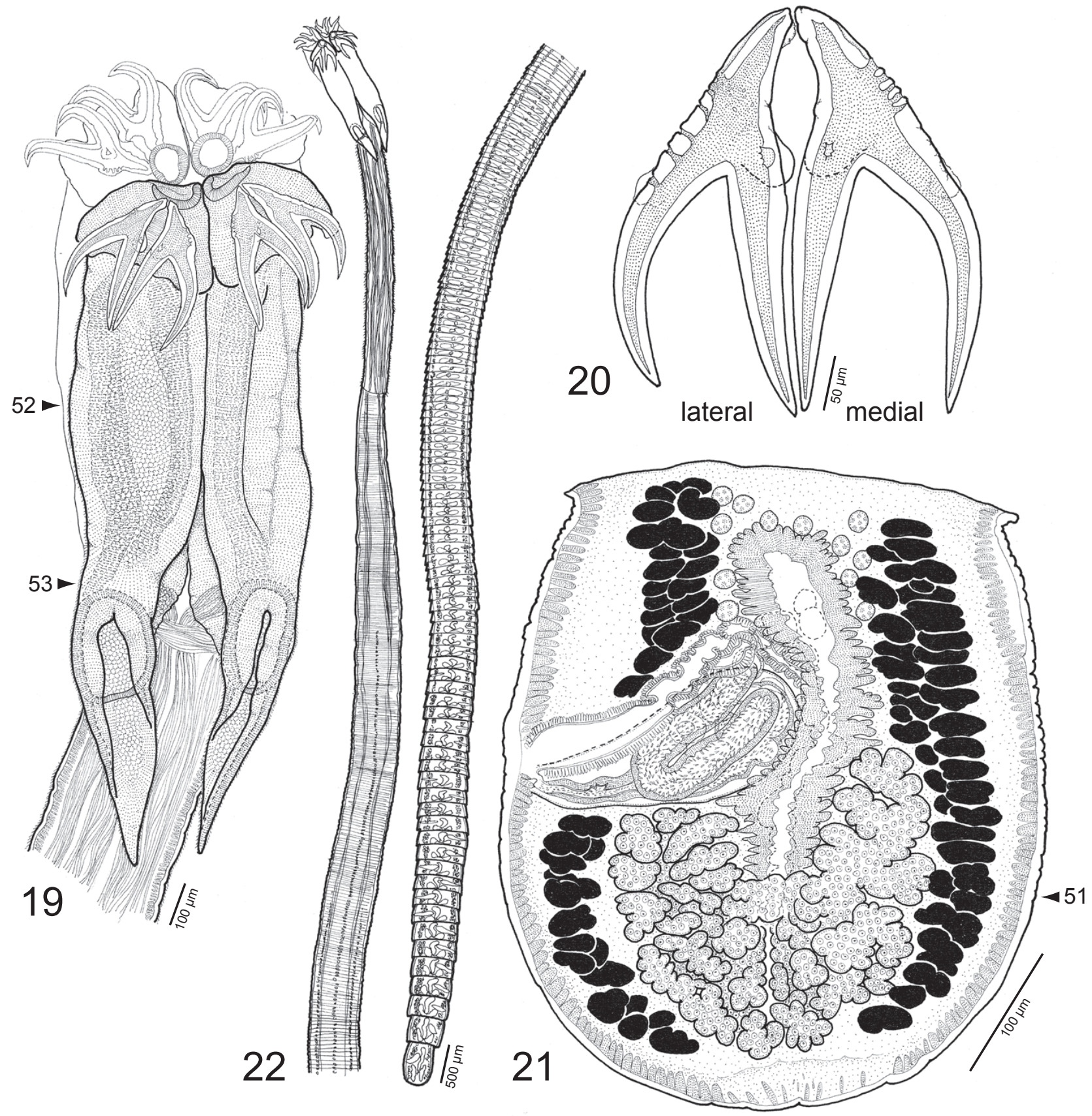

Figs. 19-22. Line drawings of Acanthobothrium rodmani sp. n. Fig. 19. Scolex (QM G231354). Arrowheads indicate location of cross-sections in Figs. 52 and 53. Fig. 20. Hooks (QM G231354). Fig. 21. Terminal proglottid (LRP 4333). Arrowhead indicates location of cross-section shown in Fig. 51. Fig. 22. Whole worm (QM G231354).

of its voucher, and the scoleces and posterior portion of the strobila of 2 hologenophores): Worms 15.2-29 mm long; greatest width at level of scolex or mid-strobila; 200-270 proglottids per worm; euapolytic; genital pores marginal, irregularly alternating, 50-63\% of proglottid length from posterior end. Scolex consisting of scolex proper and extensive cephalic peduncle. Scolex proper with 4 bothridia, 1.5-1.9 mm long by 550-690 wide. Bothridia free posteriorly, 289-395 wide; each with 3 loculi and specialised anterior region in form of muscular pad; muscular pad 175-262 long by 317-399 wide, bearing apical sucker and 1 pair of hooks below posterior margin, triangular in shape, with relatively inconspicuous posterior margins; apical sucker 92-136 long by 108-139 wide; anterior loculus 787-1,170 long; middle loculus 184-250 long; posterior loculus 340-430 long, conspicuously tapered and reflexed distally; loculus length ratio (anterior:middle:posterior) 1:0.16-0.30:0.35-0.50; maximum width of scolex at level of muscular pad. Velum present between medial margins of adjacent bothridia near 
posterior margin of anterior loculus. Hooks bipronged, hollow, with tubercle on proximal surface of axial prong; internal channels of axial and abaxial prongs continuous, smooth; axial and abaxial prongs approximately equal in length; lateral and medial hooks approximately equal in size. Lateral hook measurements: A 130-142, B 215-250, C 210-244, D 335-357. Medial hook measurements: A' 112-145, B' 210-253, C' 195-251, D' 325-361. Bases of lateral and medial hooks approximately equal in length and width, abutting along medial axis of bothridium. Bases of hooks embedded in musculature of bothridial pad. Cephalic peduncle 1.7-3.9 mm long by 267-365 wide at mid-level. Distal surfaces of apical pad covered with short filitriches. Distal surface of anterior loculus covered with densely arranged blade-like spinitriches and long filitriches (Fig. 30). Distal surfaces of middle and posterior loculi covered with medium filitriches (Fig. 29). Proximal bothridial surfaces with blade-like spinitriches (Fig. 31) interspersed with long filitriches throughout. Bothridial margins with long filitriches. Cephalic peduncle covered with densely arranged blade-like spinitriches (Fig. 32) interspersed with relatively long filitriches.

Proglottids acraspedote, protandrous. Immature proglottids 191-263 in number; mature proglottids 1-9 in number. Terminal mature proglottid $370-1,500$ long by 323-470 wide, length:width ratio 0.89-3.2:1. Gravid proglottids not observed. Testes approximately round in dorsal or ventral view, 13-26 long by 17-32 wide, arranged in multiple irregular columns anterior to ovarian isthmus, 1 layer deep, 17-26 in total number, 1-3 in postporal field, none posterior to ovarian isthmus, partly or completely atrophied in mature proglottids. Cirrus sac ovoid, tilted slightly anteriorly, 190-234 long by 72-119 wide, containing coiled cirrus; cirrus expanded at base; base and some of length of cirrus conspicuously covered with spinitriches. Vagina thick-walled, sinuous, 418-617 long, extending from ootype along medial line of proglottid to anterior margin of cirrus sac then laterally following anterior margin of cirrus sac to common genital atrium; vaginal sphincter absent; seminal receptacle not seen. Ovary occupying posterior half of proglottid, essentially asymmetrical, 166-230 wide at level of isthmus, H-shaped in frontal view, tetralobed in cross-section, conspicuously lobulated; poral arm 169-285 long; aporal arm 198-307; ovarian isthmus at midpoint of ovary. Mehlis' gland posterior to ovarian isthmus. Vitellarium follicular, consisting of 2 lateral bands; each band consisting of several columns of moderately sized follicles, extending from near anterior margin of proglottid to posterior of proglottid, interrupted by vagina and cirrus sac, not interrupted by ovary; vitelline follicles 11-22 long by 22-41 wide. Uterus thick-walled, sacciform, extending from near anterior margin of proglottid to ovarian isthmus. Excretory ducts lateral, in one dorsal and one ventral pair. Eggs not observed.
Type host: Himantura sp. (Rajiformes: Dasyatidae).

Type locality: Arafura Sea $\left(11^{\circ} 17^{\prime} 44^{\prime \prime} \mathrm{S}, 136^{\circ} 59^{\prime} 48^{\prime \prime} \mathrm{E}\right)$, east of Wessel Islands, Northern Territory, Australia.

Date of collection: November 17, 1999.

Site of infection: Spiral intestine.

Type material: Holotype (QM G231354), 3 paratypes (QM G231355-G231357), 3 paratypes (USNPC 101961101963), 3 paratypes (LRP 4333-4335), cross-sections of proglottid of 1 paratype (G231359) and corresponding voucher (QM G231358), cross-sections of scolex of 1 paratype (LRP 4564-4569) and corresponding voucher (LRP 4563 ), longitudinal sections of scolex of 1 paratype (4560 4562 ) and corresponding voucher (LRP 4559), 3 paratypes prepared for SEM (LRP 4336-4339), 2 paratype hologenophores (LRP 4340: GenBank No. FJ843596 [CF-87]; LRP 4341: GenBank No. FJ843597 [CF-124]).

Additional materia1: Two vouchers (IPCAS C-524).

E ty mology: This perky, prickly tapeworm is named in honour of Dr. James E. Rodman, formerly of the National Science Foundation, for his amazing vision, unwavering leadership, exceptional wit and perky demeanour.

Remarks. Acanthobothrium rodmani sp. n. is a category 6 species according to the categories of Acanthobothrium species determined by Ghoshroy and Caira (2001) (i.e., $>15 \mathrm{~mm}$ in total length, $>50$ proglottids, $\leq 80$ testes, and has an asymmetrical ovary). It differs from all 10 of its category 6 congeners, and also from all of its remaining congeners in its possession of bothridia that are conspicuously tapered posteriorly and reflexed anteriorly. It is also remarkable among Acanthobothrium species in general in its possession of densely arranged blade-like spinitriches on the distal surfaces of its anterior bothridial loculi. To our knowledge, among species of Acanthobothrium, to date only $A$. santarosaliense Caira et Zahner, 2001 has been reported to possess spinitriches on its distal bothridial surfaces, albeit sparsely distributed.

Cross-sections through the scolex of $A$. rodmani sp. n. reveal the bothridia of this species to be generally consistent in configuration with the bothridia of other tetraphyllideans (e.g., see Caira et al. 1999, 2001). However, it differs somewhat from the basic pattern seen in many other species in that each bothridium includes multiple bands of longitudinal muscle fibres embedded among the dorso-ventral fibres (Fig. 52). In addition, the bothridia are conspicuously free posteriorly, appearing almost stalked at their posterior margins (Fig. 53). Longitudinal sections through the septa on the face of the bothridia (Fig. 54) show that the septa of $A$. rodmani sp. n. are longer than those seen in many species and are distally rounded, rather than tapered (e.g., see Caira 1990). However, there does not otherwise appear to be anything remarkable about the configuration of the bothridia that might explain the unusual fact that the distal surfaces of the anterior loculus and its septum bear spiniform microtriches in this species. This is by far the largest of the species parasitizing Himantura sp., reaching a length of up to $29 \mathrm{~mm}$. 
Acanthobothrium romanowi sp. $\mathrm{n}$.

Figs. 23-26, 33-38, 55

Description (based on whole mounts of 10 mature worms, cross-sections of mature proglottids of 2 worms and whole mounts of their vouchers, 4 scoleces examined with SEM and whole mounts of their vouchers, and the scoleces and posterior portion of the strobila of 2 hologenophores): Worms 4-7.1 mm long; greatest width at level of scolex; 17-24 proglottids per worm; euapolytic; genital pores marginal, irregularly alternating, $34-45 \%$ of proglottid length from posterior end. Scolex consisting of scolex proper and conspicuous cephalic peduncle. Scolex proper with 4 bothridia, 320-449 long by 300-390 wide. Bothridia free posteriorly, 154-215 wide; each with 3 loculi and specialised anterior region in form of muscular pad; muscular pad 88-145 long by 113-168 wide, bearing apical sucker and 1 pair of hooks below posterior margin, triangular in shape, with conspicuously thickened apical margin, posterior margins pronounced; apical sucker 4570 long by $45-81$ wide; anterior loculus $125-180$ long; middle loculus 49-80 long; posterior loculus 58-92 long; loculus length ratio (anterior:middle:posterior) 1:0.320.62:0.38-0.62; maximum width of scolex at level of middle loculus. Velum present between medial margins of adjacent bothridia anterior margin of posterior loculus. Hooks bipronged, hollow, with tubercle on proximal surface of axial prong; internal channels of axial and abaxial prongs continuous, smooth; axial prongs longer than abaxial prongs; lateral and medial hooks approximately equal in size. Lateral hook measurements: A 48-62, B 84-93, C 65-75, D 129-148. Medial hook measurements: A' 48-60, B' 88-100, C' 63-74, D' 131-148. Bases of lateral and medial hooks approximately equal in length and width; base of lateral hook overlapping base of medial hook. Bases of hooks embedded in musculature of bothridial pad. Cephalic peduncle 140-246 long by 118148 wide at mid-level. Apical pad (Figs. 34, 35) and distal bothridial surfaces (Fig. 36) covered with short filitriches. Proximal bothridial surfaces with blade-like spinitriches (Fig. 37) interspersed with long filitriches throughout. Bothridial rims with long filitriches. Cephalic peduncle covered with densely arranged blade-like spinitriches (Fig. 38) interspersed with relatively long filitriches.

Proglottids acraspedote, protandrous. Immature proglottids $16-23$ in number; mature proglottids $1-2$ in number. Terminal mature proglottid $990-1,550$ long by 218-298 wide, length:width ratio 3.8-5.8:1. Gravid proglottids not observed. Testes irregularly oval in dorsal or ventral view, 28-59 long by 39-65 wide, arranged in 2 regular columns anterior to ovarian isthmus, 1 layer deep, 34-53 in total number, 0-2 in postporal field, none posterior to ovarian isthmus, conspicuously visible in mature proglottids. Cirrus sac ovoid, 113-173 long by 60-115 wide, containing coiled cirrus; cirrus expanded at base; base and some of length of cirrus covered with spinitriches. Vagina relatively thick-walled, sinuous, 310-466 long, extending from ootype along medial line of proglottid to anterior margin of cirrus sac then laterally following anterior margin of cirrus sac to common genital atrium; vaginal sphincter absent; seminal receptacle not seen. Ovary occupying posterior one-third of proglottid, symmetrical, 222-426 long, 93-181 wide at level of isthmus, H-shaped in frontal view, tetralobed in crosssection, conspicuously lobulated; ovarian isthmus at midpoint of ovary. Mehlis' gland posterior to ovarian isthmus. Vitellarium follicular, consisting of 2 lateral bands; each band consisting of 2 columns of small follicles, extending from near anterior margin of proglottid, stopping short of posterior margin of ovary, interrupted by vagina and cirrus sac, not interrupted by ovary; vitelline follicles oval, 10-25 long by 13-43 wide. Uterus thick-walled, sacciform, extending from near anterior margin of proglottid to ovarian isthmus. Excretory ducts lateral, in one dorsal and one ventral pair. Eggs not observed.

Type host: Himantura sp. (Rajiformes: Dasyatidae).

Type locality: Arafura Sea $\left(11^{\circ} 17^{\prime} 44^{\prime \prime} \mathrm{S}, 136^{\circ} 59^{\prime} 48^{\prime \prime} \mathrm{E}\right)$ east of Wessel Islands, Northern Territory, Australia.

Date of collection: November 17, 1999.

Site of infection: Spiral intestine.

Type material: Holotype(QMG231360), 3 paratypes(QM G231361-231363), 3 paratypes (USNPC 101964-101966), 3 paratypes (LRP 4342-4344), cross-sections of 1 paratype (QM G231365) and corresponding voucher (QM G231364), cross-sections of 1 paratype and voucher (LRP 4351-4356), 4 paratypes prepared for SEM (LRP 4345-4348), 2 paratype hologenophores (LRP 4350: GenBank No. FJ843598 [CF116]; LRP 4349: GenBank No. FJ843599 [CF-123]).

Additional material: Two vouchers (IPCAS C-525).

Etymology: This species is named for Jim Romanow, of the Biology Electron Microscopy Facility at the University of Connecticut, for his remarkable dedication to the maintenance of the instruments that have so greatly facilitated our work on cestode ultrastructure over the past two decades.

Remarks. Acanthobothrium romanowi sp. n. is a category 1 species according to the categories of Acanthobothrium species determined by Ghoshroy and Caira (2001) (i.e., $\leq 15 \mathrm{~mm}$ in total length, $\leq 50$ proglottids, $\leq 80$ testes, with symmetrical ovary). It conspicuously differs from the category 1 species A. foulki, A. larsoni, A. marymichaelorum, A. saliki, and A. southwelli, in its lack of post-ovarian testes. It further differs from these and the following additional category 1 species in that its genital pore is distinctly posterior in position (i.e., $34-45 \%$ from the posterior of the proglottid rather than being located at the middle or in the anterior half of the proglottid): A. asnihae, A. clarkeae, A. dollyae, A. gnomus, A. himanturi, A. laurenbrownae, A. lepidum, A. lineatum, A. lintoni, A. martini, A. minusculus, A. monksi, A. nicoyaense, A. oceanharvestae, A. paulum, A. royi, and A. zainali. With respect to the remaining category 1 species, it possesses 

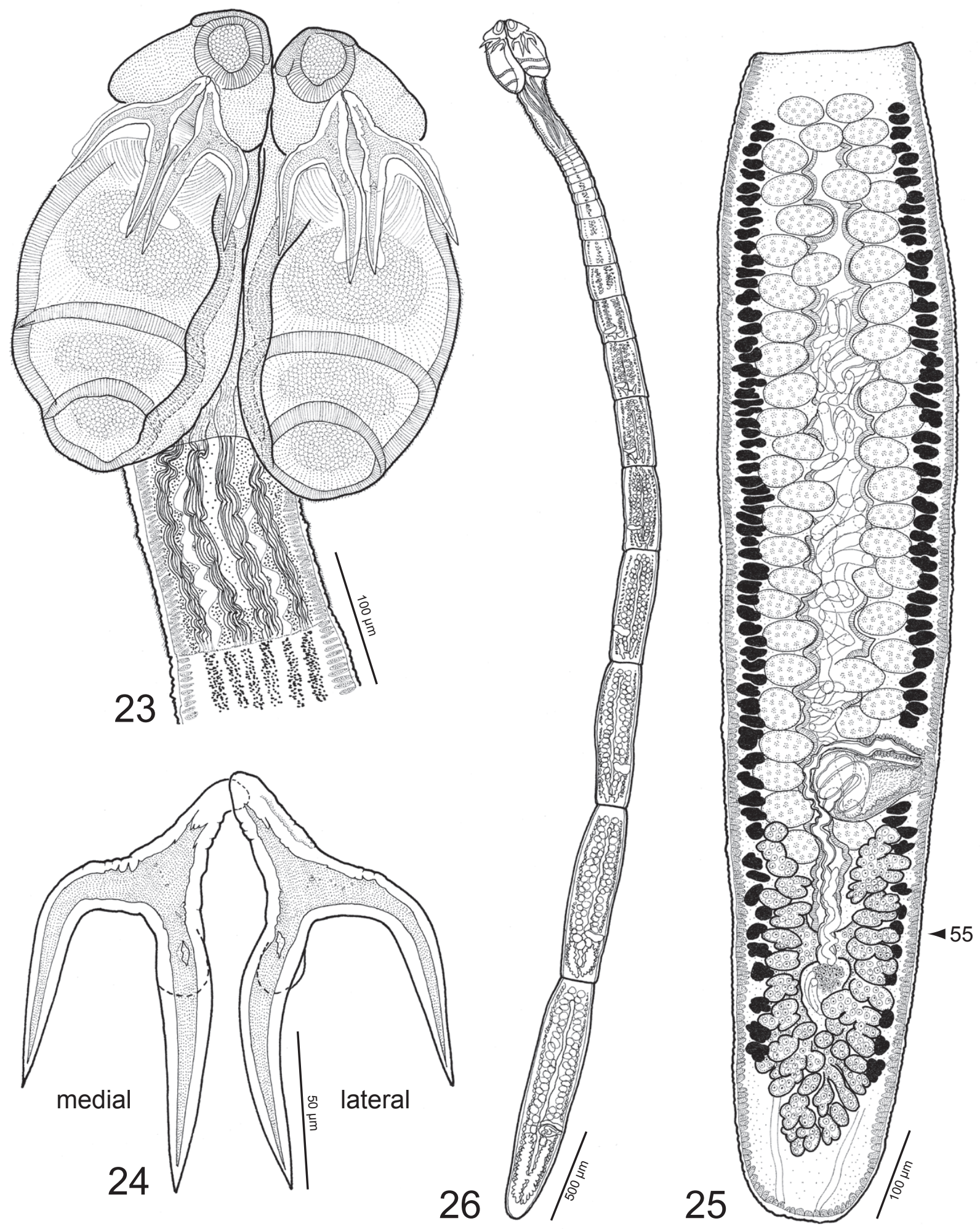

Figs. 23-26. Line drawings of Acanthobothrium romanowi sp. n. Fig. 23. Scolex (USNPC 101965). Fig. 24. Hooks (QM G231360). Fig. 25. Terminal proglottid (QM G231360). Arrowhead indicates location of cross-section shown in Fig. 55. Fig. 26. Whole worm (QM G231360). 

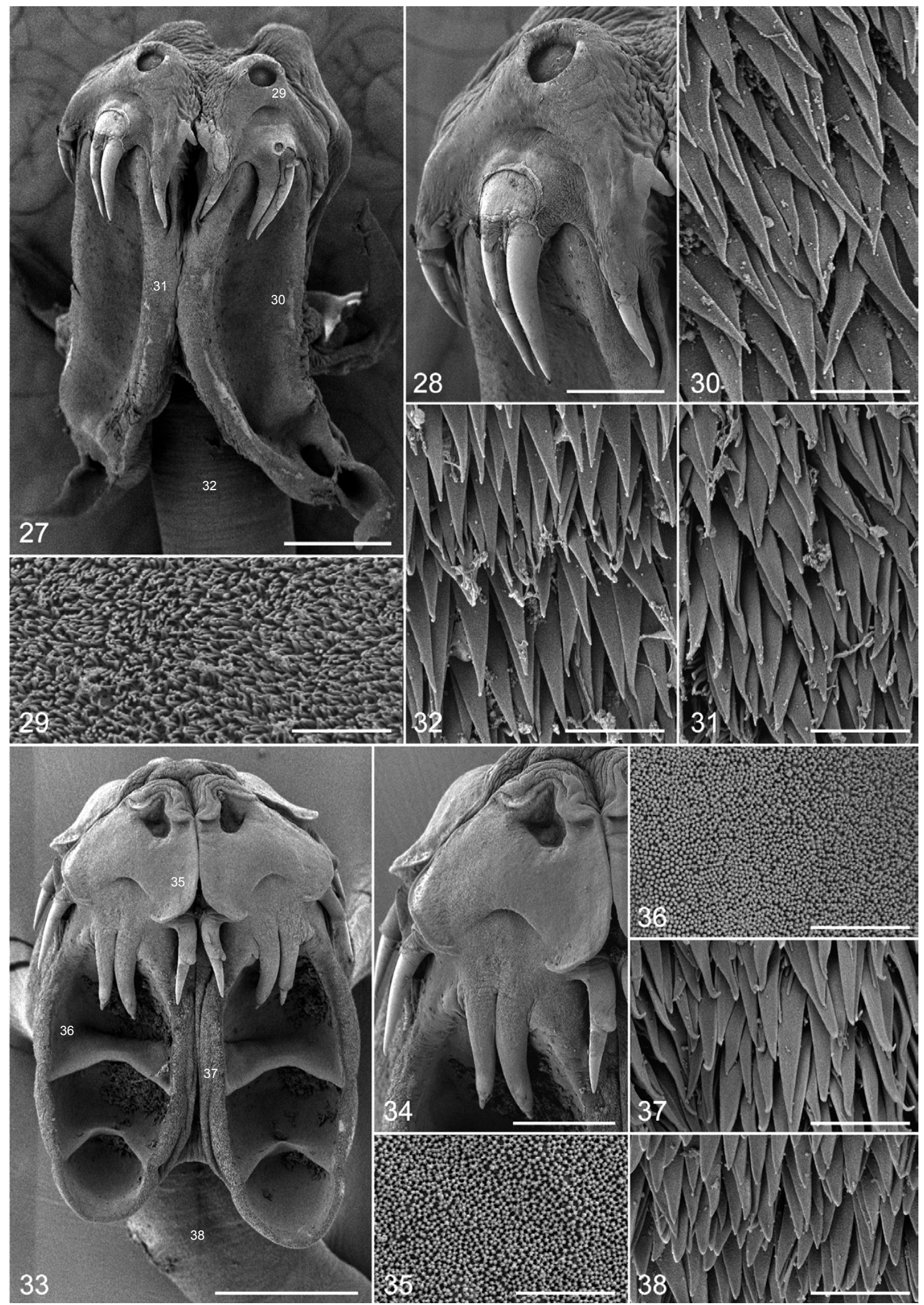

Figs. 27-32. Scanning electron micrographs of Acanthobothrium rodmani sp. n. Fig. 27. Scolex. Note: small numbers correspond to the figures showing higher magnification images of these surfaces. Fig. 28. Detail of apical pad and hooks. Fig. 29. Surface of apical pad. Fig. 30. Distal bothridial surface. Fig. 31. Proximal bothridial surface. Fig. 32. Cephalic peduncle surface. Figs. 33-38. Scanning electron micrographs of Acanthobothrium romanowi sp. n. Fig. 33. Scolex. Note: small numbers correspond to the figures showing higher magnification images of these surfaces. Fig. 34. Detail of apical pad and hooks. Fig. 35. Surface of apical pad. Fig. 36. Distal bothridial surface. Fig. 37. Proximal bothridial surface. Fig. 38. Cephalic peduncle surface. Scale bars: Fig. $27=200 \mu \mathrm{m}$; Figs. 28 , $33=100 \mu \mathrm{m}$; Fig. $34=50 \mu \mathrm{m}$; Figs. 29-32, 35-38=2 $\mu \mathrm{m}$. 
a genital pore that is anterior, rather than lateral, to the ovary as in $A$. fogeli. It is a longer worm than $A$. bartonae and $A$. rohdei (4-7.1 vs. $1.56-2.38$ and $2.1 \mathrm{~mm}$, respectively). It also possesses a greater number of proglottids than $A$. rohdei (17-24 vs. 4-6) and a greater number of testes than A. bartonae (34-53 vs. 26-29). Acanthobothrium romanowi $\mathrm{sp}$. $\mathrm{n}$. is shorter in total length than both A. urolophi and A. mathiasi (4-7.1 vs. 8-9.5 and 10$20 \mathrm{~mm}$, respectively) and lacks the distinctive elongate hair-like microtriches seen on the cephalic peduncle of A. odonaghuei. It differs from A. guptai in that its mature proglottids are distinctly longer than broad, rather than broader than long. Whereas the 3 loculi of the scolex of A. pearsoni Williams, 1962 are of equal size, the anterior loculus of $A$. romanowi sp. $\mathrm{n}$. is distinctly longer than either of the posterior 2 loculi; the former species also possesses hooks that are much more robust than those seen in the latter species. Acanthobothrium romanowi sp. n. closely resembles $A$. marplatensis, but is readily distinguished from the latter species in that its cirrus sac is distinctly oval, rather than curving conspicuously anteriorly.

Acanthobothrium zimmeri sp. n. Figs. 39-48, 56

Description (based on whole mounts of 7 mature and 2 immature worms, cross-sections of mature proglottids of 2 worms and whole mounts of their vouchers, 3 scoleces examined with SEM and whole mounts of their vouchers, and the scoleces and posterior portion of the strobila of 2 hologenophores): Worms 1.5-3.1 mm long; greatest width at level of scolex; 10-19 proglottids per worm; euapolytic; genital pores marginal, irregularly alternating, $62-72 \%$ of proglottid length from posterior end. Scolex consisting of scolex proper and cephalic peduncle. Scolex proper with 4 bothridia, 353-436 long by 182-252 wide. Bothridia free posteriorly, 92-131 wide; each with 3 loculi and specialised anterior region in form of muscular pad; muscular pad 64-90 long by 89-113 wide, bearing apical sucker and 1 pair of hooks below posterior margin, triangular in shape, with conspicuously thickened apical margin, posterior margins inconspicuous; apical sucker 27-46 long by 37-53 wide; anterior loculus 182-209 long; middle loculus 52-82 long; posterior loculus 4894 long; loculus length ratio (anterior:middle:posterior) 1:0.25-0.42:0.26-0.47; maximum width of scolex at level of middle loculus. Velum present between medial margins of adjacent bothridia at posterior margin of anterior loculus. Hooks bipronged, hollow, with tubercle on proximal surface of axial prong; internal channels of axial and abaxial prongs continuous, smooth; axial and abaxial prongs approximately equal in length; lateral and medial hooks approximately equal in size. Lateral hook measurements: A 38-45, B 67-93, C 67-94, D 95-127. Medial hook measurements: A' 33-43, B' 72-97, C' 6493, D’ 105-130. Bases of lateral and medial hooks approximately equal in length, abutting along medial axis of bothridium; medial hook base slightly wider than lateral hook base. Thin layer of tissue covering proximal half of each prong of both hooks. Bases of hooks embedded in musculature of bothridial pad. Cephalic peduncle 222420 long by 65-99 wide at mid-level. Apical pad (Figs. $44,45)$ and distal bothridial surfaces (Fig. 46) covered with short filitriches. Proximal bothridial surfaces with blade-like spinitriches (Fig. 47) interspersed with long filitriches throughout. Bothridial rims with long filitriches (Fig. 47). Cephalic peduncle covered with densely arranged blade-like spinitriches (Fig. 48) interspersed with relatively long filitriches.

Proglottids acraspedote, protandrous. Immature proglottids $10-17$ in number; mature proglottid $1-2$ in number. Terminal proglottid 429-652 long by 109-181 wide, length:width ratio 2.7-5.6:1. Gravid proglottids not observed. Testes irregularly oval in dorsal or ventral view, 25-43 long by 24-44 wide, arranged in 2 regular columns anterior to ovarian isthmus and 1-2 irregular columns posterior to ovarian isthmus, 1 layer deep, 11-19 in total number, 1-2 in postporal field, 2-6 posterior to ovarian isthmus, conspicuous in mature proglottids. Cirrus sac pyriform, 79-115 long by 53-94 wide, containing coiled cirrus; cirrus expanded at base; base and some of length of cirrus covered with spinitriches. Vagina thick-walled, sinuous, 217-328 long, extending from ootype along medial line of proglottid to anterior margin of cirrus sac then laterally following anterior margin of cirrus sac to common genital atrium; vaginal sphincter absent; seminal receptacle not seen. Ovary occupying posterior two-thirds of proglottid, symmetrical, 191-292 long, 63-94 wide at isthmus, H-shaped in frontal view, bilobed in cross-section, distinctly lobulated; ovarian isthmus anterior to midpoint of ovary. Mehlis' gland posterior to ovarian isthmus. Vitellarium follicular, consisting of 2 lateral bands; each band consisting of 2 columns of follicles, extending from near anterior margin of proglottid to near posterior margin of proglottid, interrupted by vagina and cirrus sac, not interrupted by ovary; vitelline follicles irregular, 7-22 long by 11-23 wide. Uterus thick-walled, sacciform, extending from near anterior margin of proglottid to near posterior margin of proglottid. Excretory ducts lateral, in one dorsal and one ventral pair. Eggs not observed.

Type host: Himantura sp. (Rajiformes: Dasyatidae).

Type locality: Arafura Sea $\left(11^{\circ} 17^{\prime} 44^{\prime \prime} \mathrm{S}, 136^{\circ} 59^{\prime} 48^{\prime \prime} \mathrm{E}\right)$, east of Wessel Islands, Northern Territory, Australia.

Date of collection: November 17, 1999.

Site of infection: Spiral intestine.

Type material: Holotype(QM G231366), 3 paratypes(QM G231367-G231369), 3 paratypes (USNPC 101967-101969), 2 paratypes (LRP 4357-5358), cross-sections of 1 paratype (QM G231371) and corresponding voucher (QM G231370), cross-sections of 1 paratype and voucher (LRP 4364-4366), 3 paratypes prepared for SEM (LRP 4359-4361), 2 paratype hologenophores (LRP 4363: GenBank No. FJ843602 [CF121]; LRP 4362: GenBank No. FJ843603 [CF-122]). 
Fyler et al.: Five new species of Acanthobothrium
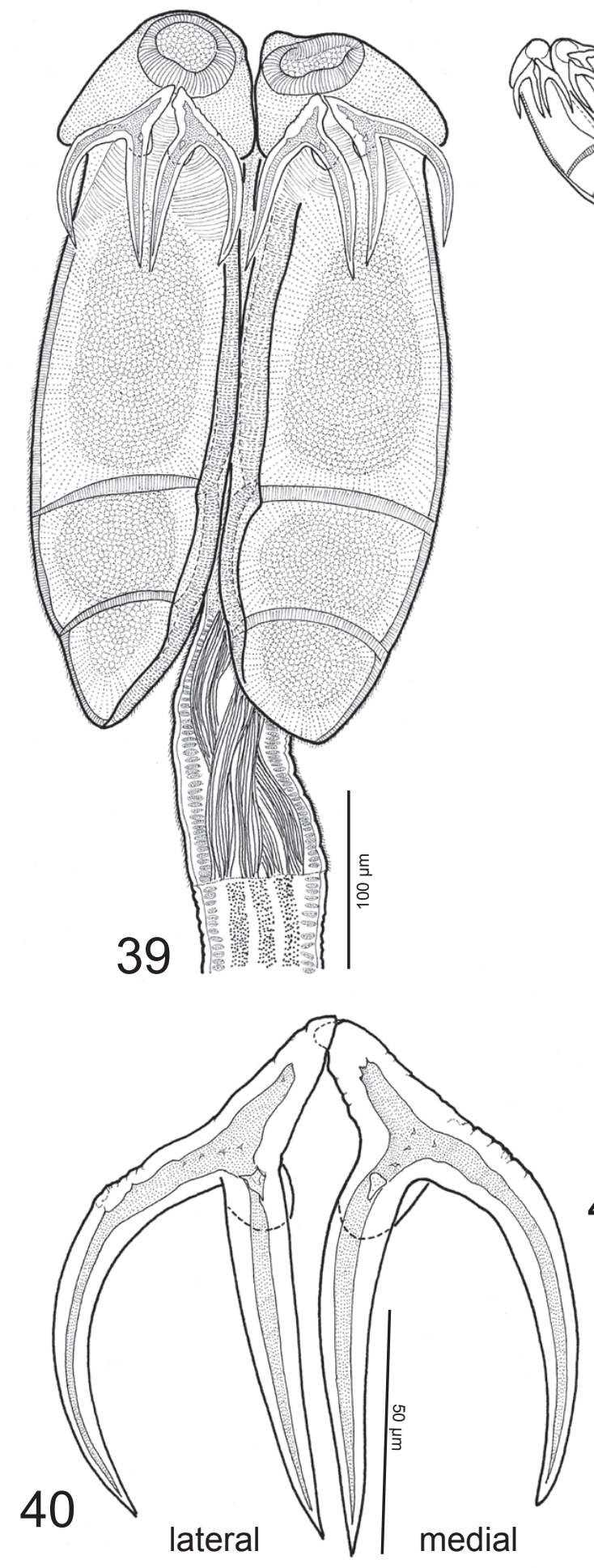

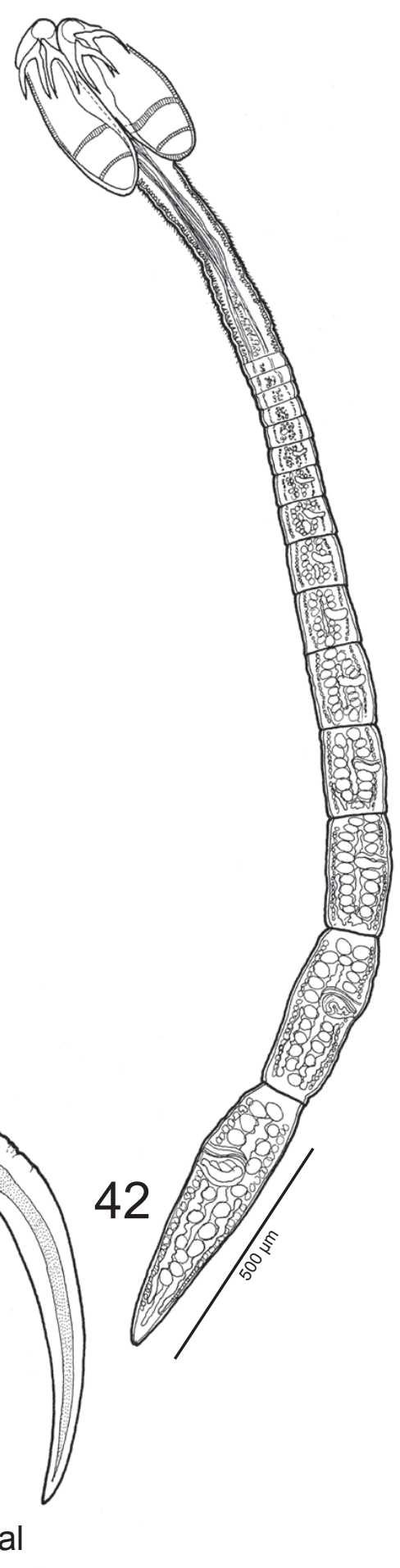

Figs. 39-42. Line drawings of Acanthobothrium zimmeri sp. n. Fig. 39. Scolex (USNPC 101967). Fig. 40. Hooks (USNPC 101967). Fig. 41. Terminal proglottid (QM G231366). Arrowhead indicates location of cross-section shown in Fig. 56. Fig. 42. Whole worm (QM G231366). 

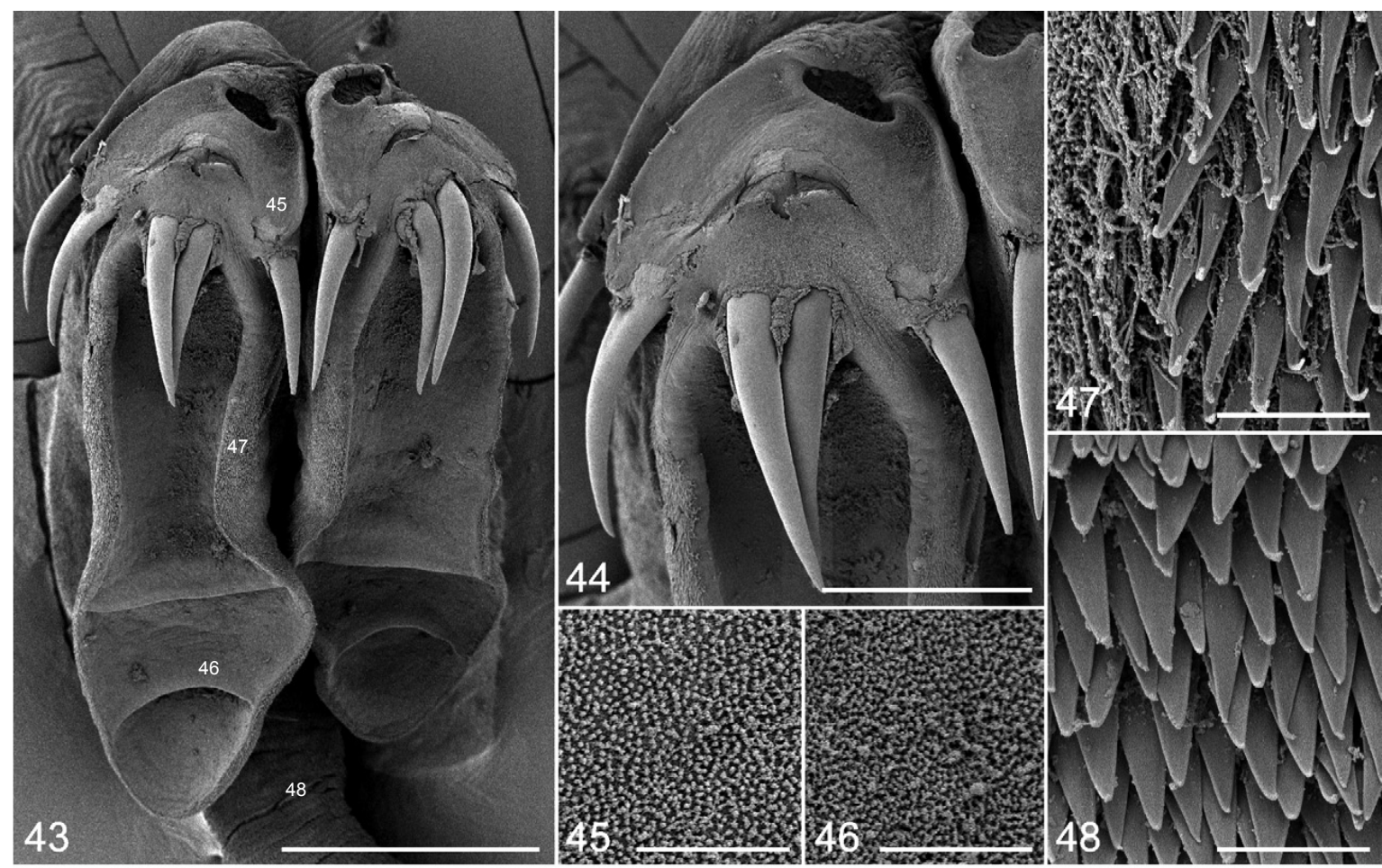

Figs. 43-48. Scanning electron micrographs of Acanthobothrium zimmeri sp. n. Fig. 43. Scolex. Note: small numbers correspond to the figures showing higher magnification images of these surfaces. Fig. 44. Detail of apical pad and hooks. Fig. 45. Surface of apical pad. Fig. 46. Distal bothridial surface. Fig. 47. Proximal bothridial surface. Fig. 48. Cephalic peduncle surface. Scale bars: Fig. $43=100 \mu \mathrm{m}$; Fig. $44=50 \mu \mathrm{m}$; Figs. $45-48=2 \mu \mathrm{m}$.

Additional material: Two vouchers (IPCAS C-526).

Etymology: This species is named for Carl Zimmer who, through his colourful contributions to the popular literature, has done much to enhance the reputation of parasites.

Remarks. Acanthobothrium zimmeri sp. n. is a category 1 species according to the criteria established by Ghoshroy and Caira (2001) (i.e., $\leq 15 \mathrm{~mm}$ in total length, $\leq 50$ proglottids, $\leq 80$ testes, with symmetrical ovary). It differs from all but 5 of the existing 32 category 1 species (i.e., including $A$. oceanharvestae and $A$. romanowi) in its possession of post-ovarian testes. With respect to the 5 species with post-ovarian testes, it possesses a greater number of proglottids (10-19 vs. 6-8) and fewer postporal testes (1-2 vs. 3-4) than A. marymichaelorum. It differs from $A$. saliki in its possession of a longer scolex proper (353-436 vs. 241-331), an anterior loculus that is correspondingly longer (182-209 vs. 153-181), and a cirrus sac that is pyriform bearing spinitriches that are barely visible, rather than oval with cirrus spinitriches that are conspicuous. It can be distinguished from A. larsoni in that it possesses fewer testes (11-19 vs. 20-29) and an ovary that is asymmetrical rather than essentially symmetrical. With respect to $A$. foulki, it possesses a muscular pad that is longer (64-90 vs. 50-60) and narrower (89113 vs. $115-137)$ and a shorter posterior loculus (48-94 vs. 95-125). It further differs from A. foulki in that its vas deferens remains a small sperm-filled tube even in fully mature proglottids, whereas the vas deferens is extensive and, when filled with sperm, obscures many of the testes in A. foulki. Acanthobothrium zimmeri sp. n. possesses fewer testes (11-19 vs. "about 34"), is a smaller worm (1.5-3.1 vs. $5 \mathrm{~mm})$, and has a greater number of proglottids (10-19 vs. 7) than $A$. southwelli.

\section{Key to species of Acanthobothrium parasitizing Himantura sp.}

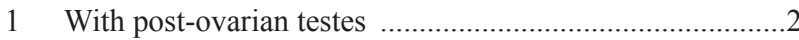

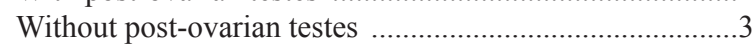

2 Total number of testes greater than 30 ; ovary asymmetrical .................................................................... A. popi Total number of testes less than 20; ovary symmetrical ...... A. zimmeri

3 Total number of proglottids 200-270; posterior loculus conspicuously pointed .................................. A. rodmani

- Total number of proglottids less than 30; posterior loculus rounded 4

4 Genital pore in posterior half of proglottid; ovary in posterior third of proglottid .................................. A. romanowi Genital pore in anterior half of proglottid; ovary extending into anterior half of proglottid .............. A. oceanharvestae 
Table 1. Measurements of new Acanthobothrium species.*

\begin{tabular}{|c|c|c|c|c|c|}
\hline \multirow{2}{*}{$\begin{array}{l}\text { Character } \\
\text { Total length (mm) }\end{array}$} & \multicolumn{2}{|c|}{ A. oceanharvestae sp. n. A. popi sp. n. } & \multirow{2}{*}{$\begin{array}{l}\text { A. rodmani sp. n. } \\
22.5 \pm 4.5 ; 10\end{array}$} & \multirow{2}{*}{$\begin{array}{l}\text { A. romanowi sp. } \mathrm{n} \text {. } \\
5.7 \pm 1.1 ; 10\end{array}$} & \multirow{2}{*}{$\begin{array}{l}\text { A. zimmeri sp. n. } \\
2.6 \pm 0.6 ; 9\end{array}$} \\
\hline & $3.5 \pm 0.3 ; 7$ & $5.3 \pm 1.2 ; 7$ & & & \\
\hline Total No. proglottids & $11.7 \pm 1.9 ; 7$ & $16.6 \pm 2.4 ; 7$ & $228 \pm 30.1 ; 10$ & $21.9 \pm 2.4 ; 10$ & $15.4 \pm 2.7 ; 9$ \\
\hline Genital pore position** & $62.4 \pm 2.1 ; 9$ & $66.9 \pm 2.7 ; 9$ & $56.9 \pm 3.8 ; 10$ & $39.6 \pm 3.8 ; 10$ & $66.5 \pm 3.2 ; 9$ \\
\hline Scolex proper length & $419.1 \pm 28.9 ; 7$ & $500.4 \pm 58.4 ; 7$ & $1,645.6 \pm 127.8 ; 9$ & $388.5 \pm 41 ; 10$ & $385.3 \pm 26 ; 8$ \\
\hline Scolex width & $286.5 \pm 20.1 ; 7$ & $288.2 \pm 31.8 ; 7$ & $626.4 \pm 51.1 ; 9$ & $342.8 \pm 28.9 ; 10$ & $230.1 \pm 22.4 ; 9$ \\
\hline Cephalic peduncle length & $272.2 \pm 88.5 ; 6$ & $377.6 \pm 46.7 ; 7$ & $2,923.6 \pm 838.4 ; 9$ & $166.4 \pm 51.2 ; 8$ & $332.5 \pm 70.9 ; 9$ \\
\hline Cephalic peduncle width & $80.2 \pm 11.4 ; 7$ & $106.1 \pm 25.6 ; 7$ & $325.9 \pm 34.5 ; 9$ & $134.1 \pm 10.8 ; 8$ & $81.4 \pm 11.8 ; 9$ \\
\hline Bothridium width & $151.4 \pm 17.5 ; 6$ & $155.4 \pm 20 ; 6 ; 8$ & $338.7 \pm 39.5 ; 9$ & $176.2 \pm 19.2 ; 10$ & $120.9 \pm 11.8 ; 9 ; 10$ \\
\hline Muscular pad length & $95 \pm 14.8 ; 7 ; 10$ & $101.1 \pm 9.6 ; 7 ; 11$ & $217.7 \pm 28.9 ; 9$ & $113.8 \pm 18.5 ; 10 ; 12$ & $76 \pm 7.9 ; 9 ; 12$ \\
\hline Muscular pad width & $123 \pm 9.4 ; 7 ; 10$ & $136.2 \pm 16.8 ; 7 ; 11$ & $356.7 \pm 30.4 ; 9$ & $144.1 \pm 17.1 ; 10 ; 12$ & $103.6 \pm 7.9 ; 9 ; 12$ \\
\hline Accessory sucker length & $43.7 \pm 6.2 ; 7 ; 9$ & $50.5 \pm 6.9 ; 7 ; 12$ & $106.3 \pm 15.5 ; 6 ; 7$ & $55.8 \pm 7.7 ; 9 ; 11$ & $37.7 \pm 6.2 ; 9 ; 13$ \\
\hline Accessory sucker width & $51.8 \pm 5.2 ; 7 ; 9$ & $61.5 \pm 11.4 ; 7 ; 12$ & $122.5 \pm 11.3 ; 8 ; 9$ & $57.5 \pm 11.3 ; 10 ; 12$ & $44.1 \pm 4.9 ; 9 ; 13$ \\
\hline Anterior loculus length (A) & $169.9 \pm 8.4 ; 7 ; 14$ & $248.9 \pm 31 ; 7 ; 11$ & $905.5 \pm 96.6 ; 9 ; 16$ & $155.4 \pm 14.2 ; 9 ; 14$ & $193.9 \pm 9.7 ; 8 ; 16$ \\
\hline Middle loculus length (M) & $76.2 \pm 5.8 ; 7 ; 15$ & $70.6 \pm 12.5 ; 7 ; 11$ & $206.7 \pm 18.1 ; 9 ; 15$ & $66.2 \pm 9.6 ; 10 ; 16$ & $62.5 \pm 9.5 ; 8 ; 16$ \\
\hline Posterior loculus length $(\mathrm{P})$ & $86.2 \pm 10.7 ; 7 ; 13$ & $91.3 \pm 19.9 ; 7 ; 10$ & $389.3 \pm 29 ; 9 ; 13$ & $75.4 \pm 11 ; 9 ; 15$ & $71.4 \pm 11 ; 8 ; 16$ \\
\hline Loculus length ratio (A:M:P) & $\begin{array}{l}\text { 1: } 0.45: 0.51 \pm \\
0: 0.03: 0.07 ; 7 ; 13\end{array}$ & $\begin{array}{l}\text { 1: } 0.28: 0.37 \pm \\
0: 0.04: 0.05 ; 7 ; 10\end{array}$ & $\begin{array}{l}\text { 1: } 0.23: 0.43 \pm \\
0: 0.04: 0.05 ; 9 ; 13\end{array}$ & $\begin{array}{l}\text { 1: } 0.43: 0.49 \pm \\
0: 0.09: 0.07 ; 8 ; 13\end{array}$ & $\begin{array}{l}\text { 1: } 0.32: 0.37 \pm \\
0: 0.05: 0.05 ; 8 ; 16\end{array}$ \\
\hline \multicolumn{6}{|l|}{ Hook measurements } \\
\hline Lateral A & $47 \pm 2.3 ; 7 ; 13$ & $55.7 \pm 5.4 ; 7 ; 10$ & $134.1 \pm 4.5 ; 7 ; 8$ & $55.9 \pm 4.5 ; 11 ; 15$ & $40 \pm 2.5 ; 9 ; 15$ \\
\hline Lateral B & $92.6 \pm 4.1 ; 7 ; 12$ & $104.6 \pm 14.4 ; 7 ; 10$ & $229.9 \pm 13.5 ; 7 ; 8$ & $89.4 \pm 3.1 ; 10 ; 15$ & $81.4 \pm 7.1 ; 9 ; 15$ \\
\hline Lateral C & $77.2 \pm 2.7 ; 7 ; 11$ & $91.6 \pm 8.3 ; 7 ; 10$ & $229.7 \pm 12.5 ; 7 ; 8$ & $70.2 \pm 2.7 ; 10 ; 15$ & $75.5 \pm 7.2 ; 9 ; 15$ \\
\hline Lateral D & $129.8 \pm 3.9 ; 7 ; 12$ & $151.2 \pm 18.5 ; 7 ; 10$ & $344.2 \pm 10.3 ; 6 ; 7$ & $136.6 \pm 4.9 ; 10 ; 15$ & $113.3 \pm 8.3 ; 9 ; 15$ \\
\hline Medial A' & $43.8 \pm 2.5 ; 7 ; 12$ & $53.9 \pm 4.6 ; 7 ; 10$ & $127.2 \pm 11.5 ; 8 ; 10$ & $53.7 \pm 3.5 ; 10 ; 15$ & $38.1 \pm 2.5 ; 9 ; 18$ \\
\hline Medial B' & $97.9 \pm 4.4 ; 7 ; 12$ & $105.6 \pm 13.8 ; 7 ; 10$ & $231.4 \pm 13 ; 8 ; 11$ & $93.2 \pm 3.6 ; 10 ; 15$ & $83.8 \pm 6.6 ; 9 ; 18$ \\
\hline Medial C' & $75.5 \pm 4.3 ; 7 ; 12$ & $99.2 \pm 7.3 ; 6 ; 9$ & $229.5 \pm 14.3 ; 8 ; 11$ & $68.8 \pm 3.4 ; 10 ; 15$ & $79.3 \pm 7.7 ; 9 ; 18$ \\
\hline Medial D' & $134.7 \pm 5.2 ; 7 ; 12$ & $155.9 \pm 17 ; 7 ; 10$ & $344.9 \pm 12.7 ; 8 ; 10$ & $140.7 \pm 5.6 ; 10 ; 15$ & $117.6 \pm 7.4 ; 9 ; 18$ \\
\hline No. immature proglottids & $10.7 \pm 1.9 ; 7$ & $15.3 \pm 2.1 ; 7$ & $222.5 \pm 30.9 ; 10$ & $20.7 \pm 2.3 ; 10$ & $14 \pm 1.9 ; 9$ \\
\hline No. mature proglottids & $0.9 \pm 0.3 ; 9$ & $1.4 \pm 0.7 ; 9$ & $5.5 \pm 2.5 ; 10$ & $1.3 \pm 0.5 ; 10$ & $1.4 \pm 0.9 ; 9$ \\
\hline Terminal proglottid length & $1,012.1 \pm 148.4 ; 9$ & $1,157 \pm 144.9 ; 8$ & $542.2 \pm 121.7 ; 10$ & $1,167.7 \pm 187.5 ; 10$ & $522.4 \pm 71.2 ; 8$ \\
\hline Terminal proglottid width & $197.3 \pm 16.3 ; 9$ & $217.2 \pm 23.8 ; 8$ & $393.2 \pm 46.6 ; 10$ & $239.6 \pm 24.9 ; 10$ & $140.8 \pm 25.7 ; 8$ \\
\hline Proglottid length:width ratio & $0.2 \pm 0.04 ; 9$ & $0.2 \pm 0.04 ; 8$ & $0.8 \pm 2.2 ; 10$ & $0.2 \pm 0.03 ; 10$ & $0.3 \pm 0.07 ; 8$ \\
\hline Total No. testes & $32.7 \pm 3.1 ; 9 ; 33$ & $45.5 \pm 2.8 ; 9 ; 28$ & $20.7 \pm 2.5 ; 7 ; 20$ & $43.7 \pm 4.3 ; 10 ; 32$ & $14.7 \pm 2.1 ; 9 ; 29$ \\
\hline No. postporal testes & $8 \pm 1 ; 9 ; 33$ & $7.2 \pm 1.1 ; 9 ; 28$ & $1.8 \pm 0.5 ; 7 ; 19$ & $1.3 \pm 0.57 ; 10 ; 32$ & $1.5 \pm 0.5 ; 9 ; 30$ \\
\hline No. postovarian testes & $0 \pm 0 ; 9 ; 33$ & $9.2 \pm 1.2 ; 9 ; 28$ & $0 \pm 0 ; 10 ; 23$ & $0 \pm 0 ; 10 ; 32$ & $4.4 \pm 0.9 ; 9 ; 30$ \\
\hline Testis length & $41.4 \pm 7.4 ; 9 ; 36$ & $36.7 \pm 5 ; 8 ; 32$ & $18.1 \pm 3.8 ; 7 ; 26$ & $39.2 \pm 8.2 ; 10 ; 40$ & $34.2 \pm 5.2 ; 8 ; 30$ \\
\hline Testis width & $48.2 \pm 8.3 ; 9 ; 36$ & $47.9 \pm 9.6 ; 8 ; 32$ & $23.7 \pm 4.1 ; 7 ; 26$ & $51 \pm 5.2 ; 10 ; 40$ & $33 \pm 4.9 ; 8 ; 30$ \\
\hline Cirrus sac length & $608.4 \pm 81.3 ; 9$ & $510.3 \pm 56 ; 8 ; 12$ & $517.8 \pm 59.2 ; 10$ & $360.4 \pm 56.9 ; 9$ & $283.4 \pm 43.1 ; 7$ \\
\hline Cirrus sac width & $109.2 \pm 12.7 ; 9$ & $137.2 \pm 14.5 ; 8$ & $215.7 \pm 12.5 ; 10$ & $134.9 \pm 17.9 ; 10$ & $96 \pm 13.6 ; 7$ \\
\hline Length of vagina & $70 \pm 15.3 ; 8$ & $92.4 \pm 21.6 ; 8$ & $96.1 \pm 15.7 ; 9$ & $80.4 \pm 17.9 ; 8$ & $72.5 \pm 14.5 ; 7$ \\
\hline Ovary length (poral arm) & $499.3 \pm 82.5 ; 9$ & $600.7 \pm 89.3 ; 8$ & $220.4 \pm 40.9 ; 10$ & $301.9 \pm 56.8 ; 10$ & $228.2 \pm 30.4 ; 7$ \\
\hline Ovary length (aporal arm) & symmetrical & $718.1 \pm 89.8 ; 8$ & $257.6 \pm 36.8 ; 10$ & symmetrical & symmetrical \\
\hline Ovary width at isthmus & $84 \pm 13 ; 9$ & $112.1 \pm 18.1 ; 7$ & $197.4 \pm 27.1 ; 9$ & $132 \pm 27.6 ; 10$ & $78.9 \pm 12 ; 7$ \\
\hline Vitelline follicle length & $14.7 \pm 3.8 ; 9 ; 35$ & $15 \pm 4 ; 8 ; 30$ & $16.1 \pm 3 ; 8 ; 32$ & $15 \pm 3.5 ; 9 ; 34$ & $14.7 \pm 4.4 ; 8 ; 24$ \\
\hline Vitelline follicle width & $18.3 \pm 3.4 ; 9 ; 35$ & $19.3 \pm 3.4 ; 8 ; 30$ & $32.2 \pm 4.5 ; 8 ; 32$ & $24.4 \pm 6.7 ; 9 ; 34$ & $15.7 \pm 2.8 ; 8 ; 24$ \\
\hline
\end{tabular}

* Measurements are given as mean, followed by standard deviation, number of worms examined, and number of total observations made if more than one observation was taken per worm; all measurements are in micrometres, unless otherwise indicated.

** Genital pore position given as percentage from posterior end of proglottid. 


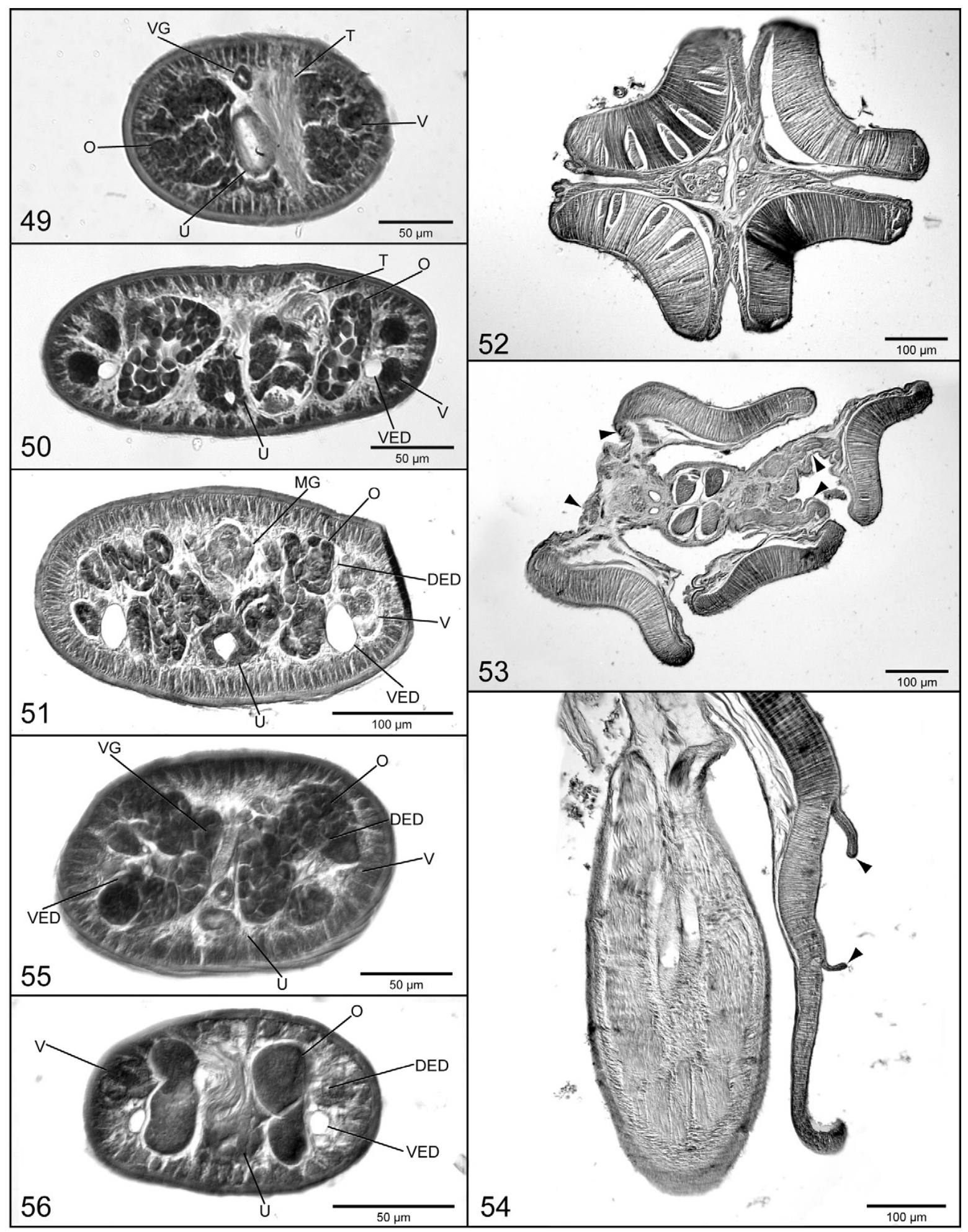

Figs. 49-56. Histological sections. Fig. 49. Cross-section through ovary of Acanthobothrium oceanharvestae sp. n. (QM G231349). Fig. 50. Cross-section through ovary of Acanthobothrium popi sp. n. (QM G231353). Fig. 51. Cross-section through ovary of Acanthobothrium rodmani sp. n. (QM G231359). Fig. 52. Cross-section through anterior region of anterior loculus of $A$. rodmani sp. n. (LRP 4564). Fig. 53. Cross-section through posterior region of anterior loculus of $A$. rodmani sp. n. (LRP 4566). Arrowheads indicate posterior stalk-like connection between bothridium and cephalic peduncle. Fig. 54. Longitudinal section through scolex showing bothridial septa of $A$. rodmani sp. n. (LRP 4561). Arrowheads indicate location of septa dividing adjacent bothridial loculi. Fig. 55. Cross-section through ovary of Acanthobothrium romanowi sp. n. (LRP 4352). Fig. 56. Cross-section through ovary of Acanthobothrium zimmeri sp. n. (QM G231371). Abbreviations: DED - dorsal excretory duct; MG - Mehlis' gland; O - ovary; $\mathrm{T}$ - testis; U - uterus; V - vitelline follicle; VED - ventral excretory duct; VG - vagina. 


\section{Molecular results}

Cestodes. The aligned 28S rDNA dataset consisted of 1,359 characters. The number of variable positions was 306 of which 242 were parsimony informative. Contiguous sequences for both specimens of all seven cestode species for which new sequence data were generated were submitted to GenBank. The accession numbers for the five new species are provided in their respective taxonomic summaries above; accession numbers for the remaining specimens are as follows: A. masnihae (FJ843604 [CF-138] and FJ843605 [CF-143]) and the undescribed species of Acanthobothrium from Himantura lobistoma (FJ843592 [CF-53] and FJ843593 [CF-134]). Pairwise distances for all pairs of species (and specimens) are given in Fig. 57. While no differences were found between the replicate specimens of any of the seven species (i.e., no intraspecific variation was found), sequence divergence among species (i.e., interspecific variation) was found to range from a minimum of $0.7 \%$ between Acanthobothrium oceanharvestae and the undescribed species of Acanthobothrium from H. lobistoma to a maximum of $11.3 \%$ between A. zimmeri and Acanthobothrium sp. 1 .

$\mathrm{BI}$ and $\mathrm{ML}$ trees were inferred using the $\mathrm{GTR}+\mathrm{I}+\mathrm{G}$ model, as indicated by MrModeltest. In each replicate Bayesian analysis, stationarity was achieved by at least 10,000 generations, and $20 \%$ of the total number of trees was excluded as burn-in to assure the retention of only the trees at stationarity. Each of the three independent Bayesian analyses converged on a single 50\% majority rule consensus tree with similar $\operatorname{lnL}$ scores (i.e., -4427.80 ; -4430.55; -4427.95). This topology is shown in Fig. 57. Each of the three independent ML analyses resulted in the same single optimal tree and similar $\operatorname{lnL}$ scores (i.e., -4417.66 ; -4417.67 ; -4417.66$)$; this topology was congruent with the BI consensus topology in Fig. 57. The MP analysis resulted in two shortest trees, each 517 steps long. The strict consensus of these two trees was consistent in topology with the tree shown in Fig. 57. Nodal support for trees resulting from all three types of analyses is presented on Fig. 57 as posterior probabilities/ML bootstrap values/ MP bootstrap values; nodes with less than 50\% ML or MP bootstrap values are indicated with dashes.

Host. With respect to the identity of the host individual, referred to here as Himantura sp., 1,044 bp of ND2 sequence data were generated and submitted to GenBank (FJ896004). A Neighbour-joining analysis of this and comparable data for 15 other Indo-Pacific species of Himantura suggests that this host may represent a species new to science for it grouped outside of all 15 of these species, but most closely with $H$. granulata (Macleay). In addition, after review of the images of this host and the pup (Figs. 58, 59), Dr. Peter Last, of CSIRO Tasmania, who has worked extensively on the batoids of Australia (e.g., Last and Stevens 1994, 2009), indicated that this species is not to his knowledge represented in collections. While it is beyond the scope of this paper to describe this host species, the photos taken of the female and the pup, in combination with the sequence data generated for the host individual, were considered to be sufficient to establish an identity, if not the name of the host.

\section{DISCUSSION}

The discovery of multiple species of Acanthobothrium unique to a single batoid species, as seen here, appears to be a relatively common occurrence (e.g., see Ghoshroy and Caira 2001, Fyler and Caira 2006, and citations therein). This is the third report of an Indo-Pacific species of Himantura being parasitized by five unique species of Acanthobothrium. Reyda and Caira (2006) and Fyler and Caira (2006) reported similarly diverse faunas in Himantura uarnacoides (Bleeker) and Himantura polylepis, respectively. It should be noted, that in the present case, the Acanthobothrium fauna actually appears to exceed five species. However, as only limited material of the two additional species was available, we have refrained from describing these additional species at this time.

The existence of post-ovarian testes in species of Acanthobothrium remains an unusual condition. However, this report brings the total number of Acanthobothrium species exhibiting this feature to 10 , out of $\sim 165$ species. All 10 of these are found only in hosts from Indo-Pacific waters. To date, seven (i.e., A. cannoni, A. foulki, A. larsoni, A. marymichaelorum, A. saliki, A. popi, and A. zimmeri) are restricted to hosts of the genus Himantura (see Campbell and Beveridge 2002, Fyler and Caira 2006, Reyda and Caira 2006, Twohig et al. 2008 and the present paper). Thus, we predict that the Indo-Pacific species of Himantu$r a$ that remain to be examined for cestodes are very likely to yield additional species of Acanthobothrium exhibiting post-ovarian testes. The three other species with postovarian testes parasitize genera belonging to other batoid orders. Campbell and Beveridge (2002) reported A. blairi from Raja whitleyi (Iredale) (= Dipturus whitleyi), Robinson (1959) reported A. wedli from Raja nasuta (= Zearaja nasuta [Müller et Henle]), and Subhapradha (1955) reported A. southwelli from Rhinobatos schlegelii Müller et Henle. Thus, Indo-Pacific species belonging to these genera are also likely candidates as hosts of additional species of Acanthobothrium bearing post-ovarian testes.

The existence of multiple congeners parasitizing a single host species is a phenomenon that occurs with some regularity, not only in Acanthobothrium (e.g., Campbell and Beveridge 2002, Fyler and Caira 2006, Reyda and Caira 2006) but also in a number of other onchobothriid genera (e.g., Caira et al. 1992, 2004, Nasin et al. 1997). Although this observation has prompted discussion of the degree of relatedness among congeners parasitizing the same elasmobranch host species, the issue has gone largely untested. The cestode molecular data generated here allow the issue to be tested in earnest for the first time in one of these host/parasite systems. Despite their limited taxonomic scope with respect to the $\sim 165$ known species of 


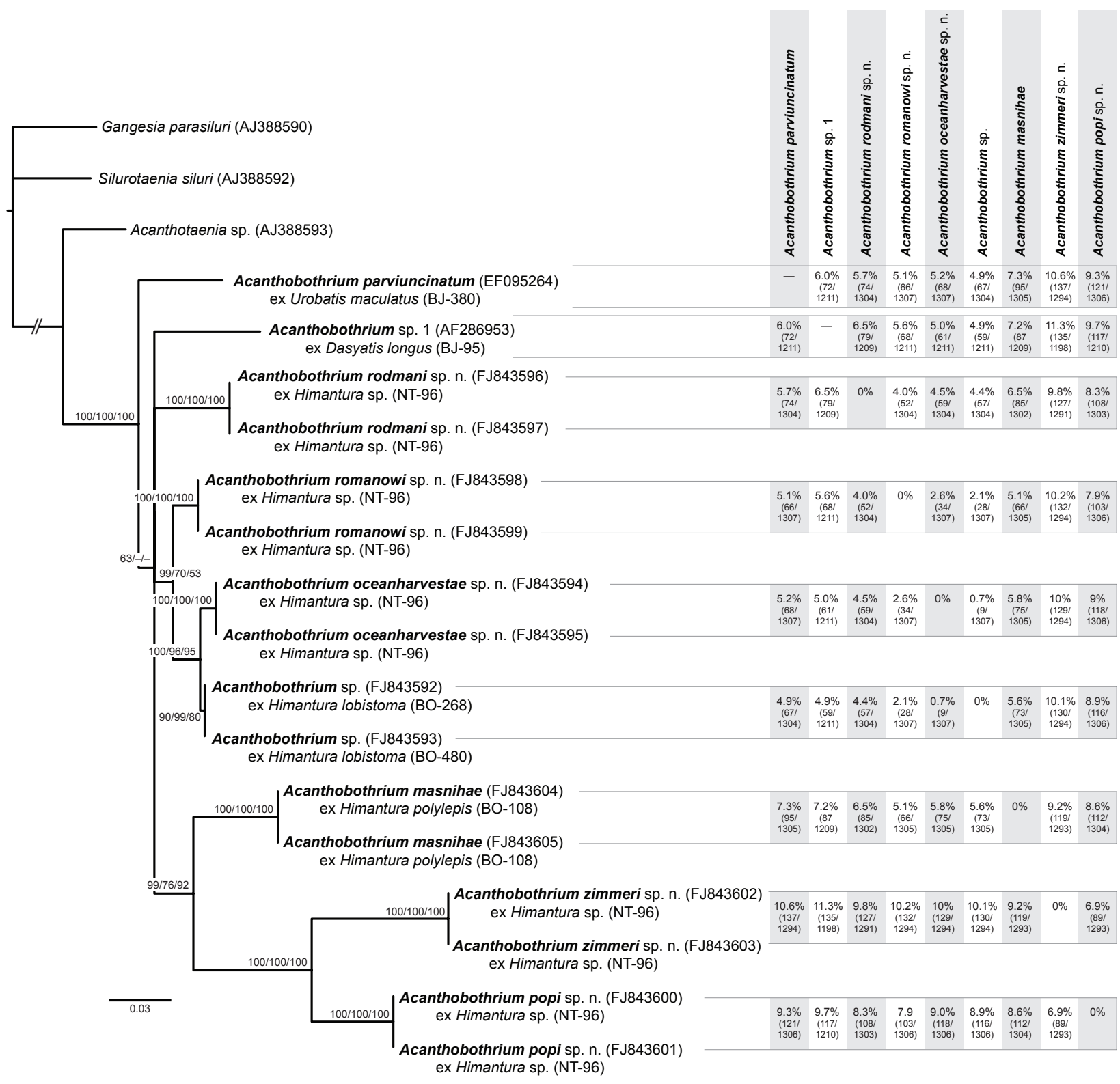

Fig. 57. Bayesian consensus tree based on analysis of $28 \mathrm{~S}$ rDNA $(-\ln L=4195.05)$ excluding gaps and ambiguous sites. Nodal support $>50$ is indicated as: BI (posterior probabilities)/ML (bootstrap, $n=100$ )/MP (bootstrap, $n=1,000$ ). Scale: number of substitutions per site. Proportion of sites differing between each Acanthobothrium species pairs is given as a percentage and in parenthesis as the number of substitutions out of the total number of bases (excluding gaps). $0 \%$ indicates identity between two specimens of a species; dash indicates species for which duplicate specimens were not investigated here.

Acanthobothrium, our data provide compelling evidence to support the notion that several of the congeners parasitizing the species (and specimen) of Himantura examined here, are not each others' closest relatives. Specifically, Acanthobothrium oceanharvestae grouped most closely with the undescribed species of Acanthobothrium from H. lobistoma, and that node was fairly well supported. Similarly, A. zimmeri and $A$. popi grouped most closely with $A$. masnihae from $H$. polylepis than with any of the other three species parasitizing Himantura sp., with that node being relatively well supported on the BI and MP tree, but less so on the ML tree. This result is interesting in light of the fact that the former two species are the only species included in the analysis that possess post-ovarian testes. However, it is important to note that the sister taxon relationship between $A$. zimmeri and $A$. popi remains to be more robustly tested in a broader context, given that $\sim 157$ of the described species of Acanthobothrium were not included in the molecular analyses conducted here, and the branch lengths of these taxa are conspicuously long relative to those of their congeners. Although Holland et al. (2009) presented 28S rDNA data for Acanthobothrium brevissime Linton, 1908, these data were determined to be too small ( $\sim 726 \mathrm{bp}$ ) for comparative purposes, and thus, to our knowledge, we have included all species of Acanthobothrium for which comparable data are currently 
available. The generation of $28 \mathrm{~S}$ rDNA data for a much broader spectrum of Acanthobothrium species would do much to resolve these questions.

It is interesting to examine divergence in $28 \mathrm{~S}$ rDNA in the context of the morphological variation seen among the species examined here. The seven Acanthobothrium species for which these data were generated de novo differ markedly from one another morphologically. Among other traits, collectively they vary in position of the genital pore (anterior one-third vs. posterior one-third of the proglottid), number of proglottids (10-270), total length (1.5-29 mm), post-ovarian testes (present or absent) and symmetry of ovary (symmetrical or asymmetrical). In fact, it could be argued that, based on morphological criteria, A. rodmani is among the most distinctive of known Acanthobothrium species; it is the only species known to possess densely arranged blade-like spinitriches on the distal surfaces of its anterior loculus and it is very conspicuous in its possession of posteriorly tapering bothridia that are reflexed anteriorly. In addition, it is conspicuously larger (maximum total length of $29 \mathrm{vs} .7 .1 \mathrm{~mm}$ in the next largest of the seven species) and has a much greater number of proglottids (up to 270 proglottids vs. a maximum of 24) than any of the other six species. However, the differences seen in the $28 \mathrm{~S}$ rDNA sequence data do not reflect this morphological divergence. The pairwise distances (Fig. 57) suggest that $A$. rodmani is only moderately divergent from most of the other species examined here with a mean distance from all eight other included Acanthobothrium species of $6.2 \pm 2 \%$ (4-9.8\%). In contrast to, for example, a mean of $9.9 \pm 1.4 \%(6.9-11.3 \%)$ for A. zimmeri, and $8.7 \pm 1 \%(6.9-10.1 \%)$ for $A$. popi, both of which were found to be substantially more divergent from most of the other species included in this analysis than was $A$. rodmani. Of course, it is important to recognize that the molecular data generated here come from only a portion $(\sim 1,300 \mathrm{bp})$ of only a single nuclear gene; determination of differences between these species using different molecular markers would be extremely interesting to explore.

The identity of the host animal from which the species described here were collected remains problematic. It is our hope that the inclusion of an image of the adult specimen and her pup, along with the deposition of ND2 sequence data, will allow the identity of this host species, and thus the type host of the five new cestode species described here, to ultimately be determined once more in-
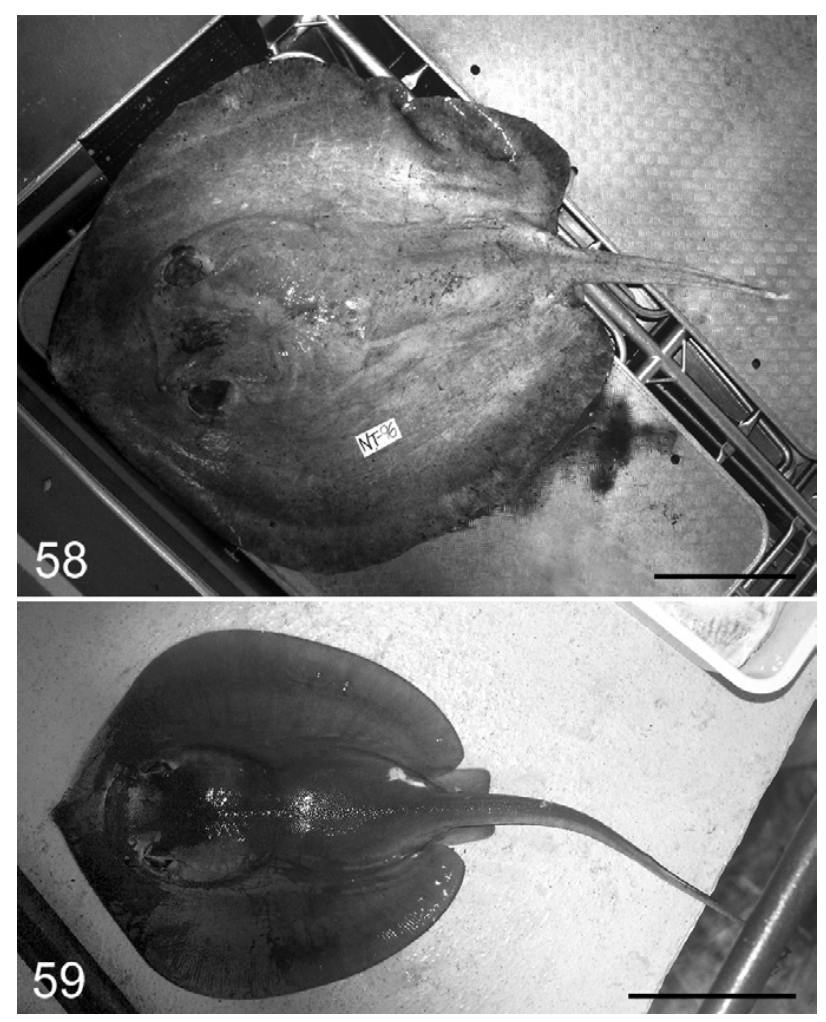

Fig. 58. Dorsal view of adult female of Himantura sp. (host specimen No. NT-96). Fig. 59. Dorsal view of pup from female in Fig. 58. Scale bars: Fig. $58=50 \mathrm{~cm}$; Fig. $59=10 \mathrm{~cm}$.

tensive work has been conducted on the rays of the waters off northern Australia.

Acknowledgements. We are enormously grateful to Bill and Ray Passey for accommodating $\mathrm{JNC}$ and $\mathrm{KJ}$ on the F.V. Ocean Harvest in November of 1999 thereby providing an invaluable opportunity for the collection of fresh samples from a diversity of large elasmobranchs. We thank Elizabeth Jockusch for providing CAF access to her molecular facilities for the generation of the 28S data. We are greatly indebted to Dr. Gavin Naylor for conducting the ND2 sequence work on the specimen of Himantura sp. The University of Connecticut Bioinformatics Facility provided computing resources for the BI and ML phylogenetic analyses performed for this study. We also thank Dr. Peter Last for providing expert advice on the identification of the host specimen examined here. This work was supported with funds from National Science Foundation PEET grant DEB 0118882 and PBI grants DEB 0818696 and DEB 0818823.

\section{REFERENCES}

CAIRA J.N. 1990: The tapeworm Spiniloculus mavensis (Tetraphyllidea: Onchobothriidae) from the brown banded bambooshark in Australia. Aust. J. Zool. 37: 705-710.

CAIRA J.N. 1992: Verification of multiple species of Pedibothrium in the Atlantic nurseshark with comments on the Australasian members of the genus. J. Parasitol. 78: 289-308.
Caira J.N., Jensen K., Healy C.J. 1999: On the phylogenetic relationships among tetraphyllidean, lecanicephalidean and diphyllidean tapeworm genera. Syst. Parasitol. 42: 77-151.

Caira J.N., Jensen K., Healy C.J. 2001: Interrelationships among tetraphyllidean and lecanicephalidean cestodes. In: D.T.J. Littlewood and R.A. Bray (Eds.), Interrelationships of the Platyhelminthes. Taylor and Francis, London, pp. 135-158. 
Caira J.N., Mega J., Ruhnke T.R. 2005: An unusual blood sequestering tapeworm (Sanguilevator yearsleyi n. gen., n. sp. from Borneo with description of Cathetocephalus resendezi n. sp. from Mexico and molecular support for the recognition of the order Cathetocephalidea (Platyhelminthes: Eucestoda). Int. J. Parasitol. 35: 1135-1152.

Caira J.N., Tracy R., Euzet L. 2004: Five new species of Pedibothrium (Tetraphyllidea: Onchobothriidae) from the tawny nurse shark, Nebrius ferrugineus, in the Pacific Ocean. J. Parasitol. 90: 286-300.

Campbell R.A., Beveridge I. 2002: The genus Acanthobothrium (Cestoda: Tetraphyllidea: Onchobothriidae) parasitic in Australian elasmobranch fishes. Invertebr. Syst. 16: 237-344.

de Chambrier A., Zehnder M., Vaucher C., Mariaux J. 2004: The evolution of the Proteocephalidea (Platyhelminthes, Eucestoda) based on an enlarged molecular phylogeny, with comments on their uterine development. Syst. Parasitol. 57: 159-171.

Euzet L. 1959: Recherches sur les cestodes tétraphyllides des sélaciens des côtes de France. Thèse, Faculté des Sciences Naturelles, Université de Montpellier. Montpellier, France, 263 pp.

Faliex E., Tyler G.A, Euzet L. 2000: A new species of Ditrachybothridium (Cestoda: Diphyllidea) from Galeus sp. (Selachii, Scyliorhinidae) from the South Pacific Ocean, with a revision of the diagnosis of the order, family, and genus and notes on descriptive terminology of microtriches. J. Parasitol. 86: 10781084.

Fyler C.A., Caira J.N. 2006: Five new species of Acanthobothrium (Tetraphyllidea: Onchobothriidae) from the freshwater stingray Himantura chaophraya (Batoidea: Dasyatidae) in Malaysian Borneo. J. Parasitol. 92: 105-125.

Ghoshroy S., Caira J.N. 2001: Four new species of Acanthobothrium (Cestoda: Tetraphyllidea) from the whiptail stingray Dasyatis brevis in the Gulf of California. J. Parasitol. 87: 354-372.

Healy C.J., Caira J.N., Jensen K., Webster B.L., Littlewood D.T.J. 2009: Proposal for a new tapeworm order, Rhinebothriidea. Int. J. Parasitol. 39: 497-511

Hillis D.M., Bull J.J. 1993: An empirical test of bootstrapping as a method for assessing confidence in phylogenetic analysis. Syst. Biol. 42: 182-192.

Hillis D.M., Mable B.K., Larson A., Davis S.D., Zimmer E.A. 1996: Nucleic acids IV: Sequencing and cloning. In C. Moritz and B.K. Mable (Eds.), Molecular Systematics. Sinauer, Sunderland, MA, pp. 321-381.

Holland N.D., Campbell T.G., Garey J.R., Holland L., Wilson N.G. 2009: The Florida amphioxus (Cephalochordata) hosts larvae of the tapeworm Acanthobothrium brevissime: natural history, anatomy and taxonomic identification of the parasite. Acta Zool. 90: 75-86.

Last P.R., Stevens J.D. 1994: Sharks and Rays of Australia. 1st Edition. CSIRO Publications, Tasmania, Australia, 513 pp.

Last P.R., Stevens J.D. 2009: Sharks and Rays of Australia. 2nd Edition. CSIRO Publications, Tasmania, Australia, $656 \mathrm{pp}$.

Maddison D.R., Maddison W.P. 2005: MacClade 4: Analysis of phylogeny and character evolution. Version 4.08. Sinauer Associates, Sunderland, Massachusetts, USA.
Nasin C., Caira J.N., Euzet L. 1997: A revision of Calliobothrium (Tetraphyllidea: Onchobothriidae) with descriptions of three new species and a cladistic analysis of the genus. J. Parasitol. 83: 714-733.

Nylander J.A.A. 2004: MrModelTest, program distributed by the author. Evolutionary Biology, Uppsala University, version 2.

Olson P.D., Littlewood D.T.J., Bray R.A., Mariaux J. 2001: Interrelationships and evolution of the tapeworms (Platyhelminthes: Cestoda). Mol. Phylogenet. Evol. 19: 443-467.

Pleijel R., Jondelius U., Norlinder E., Nygeren A., Oxelman B., Schander C., Sundberg P., Thollesson M. 2008: Phylogenies without roots? A plea for the use of vouchers in molecular phylogenetic studies. Mol. Phylogenet. Evol. 48: 369-371.

Posada D., Crandall K.A. 1998: Modeltest: testing the model of DNA substitution. Bioinformatics 14: 817-818.

Rambaut A., Drummond A.J. 2005: Tracer v1.2.1. Available from http://tree.bio.ed.ac.uk/software/tracer/

REYda F., CAIRA J.N. 2006: Five new species of Acanthobothrium (Cestoda: Tetraphyllidea) from Himantura uarnacoides (Rajiformes: Dasyatidae) in Malaysian Borneo. Comp. Parasitol. 43: 49-71.

Robinson E.S. 1959: Some new cestodes from New Zealand marine fishes. Trans. R. Soc. N. Z. 86: 381-392.

Ronquist F., Huelsenbeck J.P. 2003: MrBayes 3: Bayesian phylogenetic inference under mixed models. Bioinformatics 19: $1572-1574$.

Srivastav A.K., Capoor V.N. 1980: On Acanthobothrium dighaensis sp. n. (Onchobothriidae Braun, 1900) from Trygon marginatus. Helminthologia 17: 165-170.

SubHapRAdHA C.K. 1955: Cestode parasites of fishes of Madras. Indian J. Helminthol. 7: 41-132.

Swofford D.L. 2002: Phylogenetic analysis using parsimony. Version PAUP*4.0b10. Sinauer Associates, Sunderland, Massachusetts, USA.

Twohig M.E., Caira J.N., Fyler C.A. 2008: Two new cestode species from the dwarf whipray, Himantura walga (Batoidea: Dasyatidae), from Borneo with comments on site and mode of attachment. J. Parasitol. 94: 1118-1127.

Waeschenbach A., Webster B.L., Bray R.A., Littlewood D.T.J. 2007: Added resolution among ordinal level relationships of tapeworms (Platyhelminthes: Cestoda) with complete small and large subunit nuclear ribosomal RNA genes. Mol. Phylogenet. Evol. 45: 311-325.

Wilcox T.P., Zwickl D.J., Heath T.A., Hillis D.M. 2002: Phylogenetic relationships of the dwarf boas and a comparison of Bayesian and bootstrap measures of phylogenetic support. Mol. Phylogenet. Evol. 25: 361-371.

Zehnder M.P., Mariaux J. 1999: Molecular systematic analysis of the order Proteocephalidea (Eucestoda) based on mitochondrial and nuclear rDNA sequences. Int. J. Parasitol. 29: 1841-1852.

ZWICKL D.J. 2006: Genetic algorithm approaches for the phylogenetic analysis of large biological sequence datasets under the maximum likelihood criterion. PhD Dissertation. University of Texas at Austin, $115 \mathrm{pp}$. 